Portland State University

PDXScholar

11-29-1995

\title{
DNA Sequences Involved in the Regulation of Human c-MYC Gene Expression by Herpes Simplex Virus Type 1 (HSV-1)
}

Shanli Ye

Portland State University

Follow this and additional works at: https://pdxscholar.library.pdx.edu/open_access_etds

Part of the Biology Commons

Let us know how access to this document benefits you.

Recommended Citation

Ye, Shanli, "DNA Sequences Involved in the Regulation of Human c-MYC Gene Expression by Herpes Simplex Virus Type 1 (HSV-1)" (1995). Dissertations and Theses. Paper 5221.

https://doi.org/10.15760/etd.7097

This Thesis is brought to you for free and open access. It has been accepted for inclusion in Dissertations and Theses by an authorized administrator of PDXScholar. Please contact us if we can make this document more accessible: pdxscholar@pdx.edu. 


\section{THESIS APPROVAL}

The abstract and thesis of Shanli Ye for the Master of Science degree in Biology were presented November 29, 1995 and accepted by the thesis committee and the department.

COMMITTEE APPROVALS:

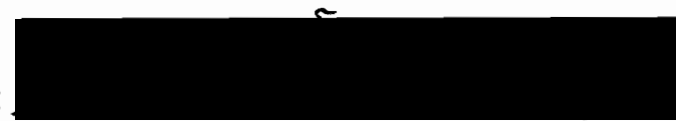
, Chair

Robert L. Millette

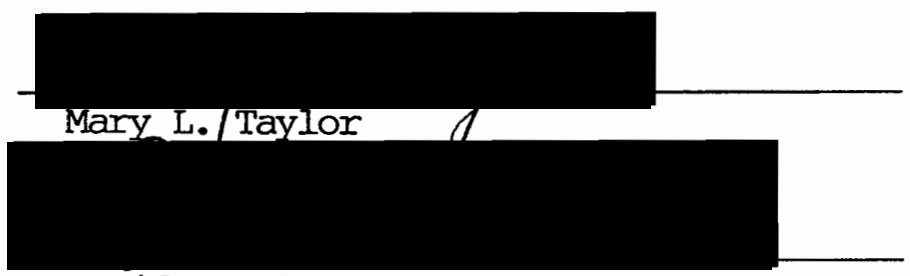

David T. Clark

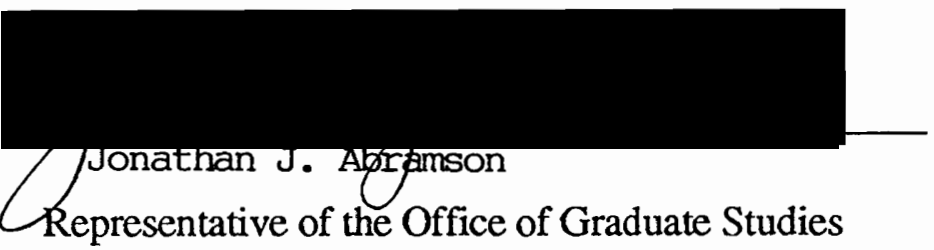

DEPARTMENT APPROVAL: Leonard Simpson, Chair Department of Biology

******************************************************

ACCEPTED FOR PORTLAND STATE UNIVERSITY BY THE LIBRARY
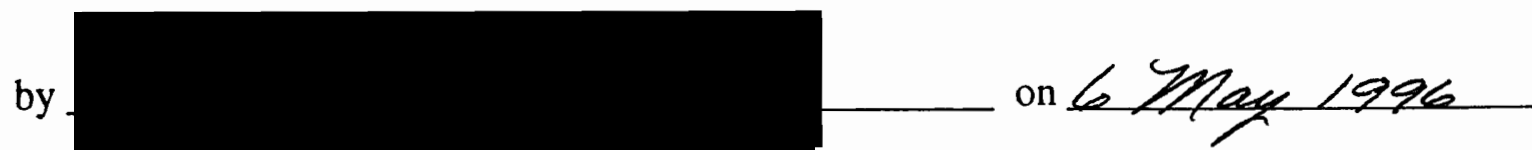


\begin{abstract}
An abstract of the thesis of Shanli Ye for the Master of Science in Biology presented November 29, 1995.
\end{abstract}

Title: DNA Sequences Involved in The Regulation of Human $c$-myc Gene Expression by Herpes Simplex Virus Type 1 (HSV-1).

The human $c$-myc gene is a cellular proto-oncogene composed of three exons and two introns. Transcription of $c$-myc is controlled by two promoters, P1 and P2. The activity of these promoters is regulated by many factors, such as cellular transcription factors E2F, YY1, and HSV-1 immediate-early proteins, ICP0, ICP4.

- Many regulatory elements located both upstream of and between P1 and P2 have been identified, and some of these are required for optimum expression of c-myc. In this thesis research, a region downstream from $\mathrm{P} 2$ in the $c$-myc exon 1 was identified by its response to transactivation by HSV-1 immediate-early proteins, ICP0 and ICP4. The purpose of this research was to examine this region for regulatory sites that respond to HSV-1 infection. I hypothesized that after HSV-1 infection, ICPO and ICP4 activate $c$-myc expression, in part, through regulatory sequences present in exon 1.

To test for this hypothesis, reporter plasmids containing (I) the $c$-myc promoter (from 101 bp relative to P1) and exon 1 coupled to the bacterial CAT gene were constructed. (ii) The $c$-myc exon sequences used were either intact (wild-type) or they were constructed with various deletions. The activities of these plasmids were examined in transient expression assays. To analyze protein binding, electrophoretic mobility shift assay (EMSA) 
and completion EMSAs were carried out. The results from these experiments lead to the following conclusions: (i) ICP4 and ICP0 serve as activators, whereas ICP27 inhibits $c$-myc gene expression. (ii) The region from +332 to +513 within the $c$-myc exon 1 contains an important element required for transactivation of the $c$-myc gene by HSV-1 proteins. (iii) Cellular proteins, including factor YY1, bind to the region from +332 to +513 in the $c$-myc exon 1.

Although the exact mechanism by which HSV-1 immediate-early proteins regulate $c$ myc gene expression is still not clear, it gives rise to a possibility that this regulation is caused by turning on or activation of the cellular regulatory proteins by ICP4 and ICP0. The cellular proteins in turn activate the $c$-myc gene expression by interacting with the $c i s$ element downstream from P2. 


\title{
DNA SEQUENCES INVOLVED IN THE REGULATION OF HUMAN $c$-MYC GENE EXPRESSION BY HERPES SIMPLEX VIRUS TYPE 1 (HSV-1)
}

\author{
by \\ SHANLI YE \\ A thesis submitted in partial fulfillment of the \\ requirements for the degree of
}

MASTER OF SCIENCE in BIOLOGY

Portland State University

1996 


\section{DNA SEQUENCES INVOLVED IN THE REGULATION OF HUMAN C-MYC GENE EXPRESSION BY HERPES SIMPLEX VIRUS TYPE 1 (HSV-1)}

\section{GENERAL BACKGROUND}

\section{PREVIOUS STUDIES ON c-MYC REGULATION}

The $c$-myc gene is the cellular homolog of the $v$-myc oncogene which was first detected as the transforming sequence of the avian myelocytomatosis virus (58). In humans, the $c$-myc gene was mapped to chromosome 8 (8q24) (5) and it is composed of three exons and two introns. Exon 2 and exon 3 contain the coding information for the $c$-myc protein, while exon 1 is an untranslated leader that is highly conserved between human and mouse (2) and entirely absent from $v$-myc (70). Within the exon 1, there are two promoters designated as $\mathrm{Pl}$ and $\mathrm{P} 2$ which are separated about 170 base pairs (for human $c$-myc gene) (33). The products encoded by $c$-myc gene are two phosphoproteins that are initiated at independent translational sites (29). These phosphoproteins are expressed at a low constitutive level in growing cells and arc down-regulated in quiescent and differentiated cells (38). They are thought to function as transcriptional activators and they are involved in the regulation of proliferation, mitogenesis, and differentiation (40). In addition thcrc is evidence that they play a role in programmed cell death (apoptosis) (52) and in the cytotoxicity of TNF- $\alpha$ in tumor cells (37).

Early studies have already revealed that overexpression of $c$-myc (or deregulation of $c$-myc expression) is related to the tumorigenesis of many kinds of human cancers such as Burkitt's lymphoma (BL), colon cancer (15), and breast cancer (16). In BL case, the c-myc gene is translocated into first intron of the immunoglobulin (Ig) heavy chain gene located on the chromosome 14 [human, $t(8,14)$ ]. The immunoglobulin enhancer element located in the intron 
causes the $c$-myc gene to bc over-expressed. This suggested that deregulation of $c$-myc expression was important for multistage carcinogenesis.

To understand how $c$-myc functions in these varied processes, it is important to understand what factors, both endogenous and exogenous, are involved in regulating the $c$-myc expression both in the normal cell cycle and in the tumor cells. We already know that $c$-myc expression is dependent on the presence of certain growth factors, e.g. platelet-derived growth factor (PDGF) (38), and on certain transcription regulatory factors such as E2F (14), YY1 (Yin Yang 1) (57), Spl (10), etc. In 1983, Kathleen Kelly et al found that $c$-myc mRNA was strongly induced (10- to 40 -fold) by mitogens (e.g. lipopolysaccharides or concanavalin A) in lymphocytes and by PDGF in fibroblasts (38). Later Nissim Hay et al demonstrated that the 2.3 kilobase pair $(\mathrm{kbp})$ region upstrcam from the first transcription start site, $\mathrm{Pl}$, contained both positive and negative regulatory elements which were involved in regulating $c$-myc expression by cellular factors (33).

Other previous studies showed that the $c$-myc expression was regulated at the level of elongation of transcription (premature termination of transcription occurs in the first exon of $c$-myc exon) (1, 14, 53). Bentley and Groudine demonstrated that when the HL60 cells (human promyelocytic leukemia cell line) differentiated into granulocytes, by means of treating the HL60 cells with retinoic acid, the $c$-myc mRNA level was reduced 10 -fold (1). With the nuclear runoff assays, they showed that this reduction was detected in the transcription of $c$-myc exon 2 but not $c$-myc exon 1 . This observation suggested that $c$-myc transcriptional down-regulation was at the level of transcriptional elongation rather than initiation, and this transcriptional elongation block occurrcd in the first exon of the $c$-myc gene (1).

One of the important findings in the regulation of human $c$-myc regulation came from a report by Hiebert et al. They found that the adenovirus pre-early (or immediate-early) protein ElA was able to activate the endogenous $c$-myc gene. By using site-directed mutagenesis of the E2F site locatcd 
at about $60 \mathrm{bp}$ upstream of the P2 in the $c$-myc exon 1, they found that the E1A transactivation was mediated by cellular protein E2F (34). This suggested that E2F might play an important rolc in activating the $c$-myc gene expression.

Another important observation is the recent report published by DesJardins and Hay. They identified and characterized six potential regulatory sites called CT boxes (i.e. cytosinc-thymidinc boxes) in the $c$-myc promoter. Five are located at upstream of $\mathrm{PI}$ and one $\left(\mathrm{CT}-\mathrm{I}_{2}\right)$ is locatcd between $\mathrm{P} 1$ and P2 (10). Using a series of deletion mutations along with transfection and electrophoretic mobility shift assays (EMSA), they found that these CT elements were binding sitcs for $\mathrm{Spl}$ and $\mathrm{Spl-related} \mathrm{zinc-finger} \mathrm{regulatory} \mathrm{proteins.} \mathrm{Spl} \mathrm{binding} \mathrm{was} \mathrm{found} \mathrm{to} \mathrm{be} \mathrm{responsiblc}$ for activating P2-initiated transcription and inhibiting P1-initiated transcription (10), and this promoter usage shift (shift the promoter usage from $\mathrm{P} 1$ to $\mathrm{P} 2$ ) was observed in the normal individual.

The early studies described above suggest that human $c$-myc gene expression is regulated at multiple stages and is regulated by multiple factors, including different cellular regulatory proteins, growth factors, viral proteins and certain mitogens. These factors may regulate $c$-myc gene expression by different mechanisms (e.g. by activating initiation of the $c$-myc transcription or blocking elongation of the $c$-myc mRNA) The activation by these factors may cause the overexpression of $c$-myc gene which can lead to multistage carcinogenesis.

\section{GENE REGULATION OF HSV-1}

In order to understand how herpes simplex virus type 1 (HSV-1) infection may be involved regulation of $c$-myc gene expression, it is necessary to introduce some general aspects of $\mathrm{HSV}-1$ replication. HSV-1 is a member of the viral family Herpesviridae and is composed of four basic structures: an envelope with viral glycoproteins, a tegument, a capsid, and a DNA-containing core. Analysis of the complete sequence of the HSV-1 genome has revealed that its genome has a total 
size $152 \mathrm{kbp}$ and contains at least 70 distinct genes (41). Based on the kinetics and charactcristics of their expression, these genes can be divided into three main classes: immediate-early genes (IE, or $\alpha$ genes), early genes ( $\mathrm{E}$, or $\beta$ genes), and latc genes (L, or $\gamma$ genes). The expression of these genes is coordinately regulated and sequentially ordered in a cascade fashion: $I E \longrightarrow E \longrightarrow L$. The expression of late (or $\gamma$ ) genes requires viral DNA replication. Based on expression time and the degrec of requirement of the DNA replication, the $\gamma$ genes are divided into two subgroups, $\gamma_{1}$ (for example, the major capsid protein, VP5, gene) and $\gamma_{2}$ (for example, the glycoprotein $\mathrm{C}, \mathrm{gC}$, gene). The $\gamma_{1}$ genes, also called $\beta \gamma$ or leaky-late genes, are late genes start their expression before the viral DNA synthesis. However their full expression need the viral DNA synthesis. Thus their expression can still be detected (in a lower amount) in the presence of DNA synthesis inhibitors. On the other hand, $\gamma_{2}$ genes are expressed after viral DNA replication and thcy have a high stringency for viral DNA synthesis. In the presence of DNA synthesis inhibitors, the expression of $\gamma_{2}$ genes is almost totally blocked. The relationship between the late genes expression and viral genome replication is not clear.

The IE class genes are defined as those which can be transcribed in the absence of de novo viral protein synthesis, and they code for five proteins (infected cell polypeptides) designated as ICP0, ICP4, ICP22, ICP27, and ICP47. Three of these immediate-early proteins, ICP4, ICP0, and ICP27, are main regulatory proteins for the HSV-1 gene expression $(7,12,19,26,51)$. ICP4 is a DNA sequence-specific binding protein $(11.20,44)$ and a phosphoprotein essential for viral replication. However, the binding of ICP4 to its consensus binding sites may not be required for its activation function (65). The ICP4 regulatory roles in the HSV genes expression have been revealed in early studies: (i) ICP4 is a major transactivator for HSV early and late gene expression; (ii) ICP4 represses its own expression and that of other $\alpha$ genes expression. These ICP4 functions were demonstrated by the study of ICP4 temperature-sensitive (ts) mutants. Dixon and Schaffer 
demonstrated that, at non-permissive temperature or in the temperature shift experiments, ICP4 ts mutants exhibited severe impairment in the expression of viral early (VP64) and late (VPI00, VP154) genes and the overproduction of the $\alpha$ genes, such as ICP4, ICP22, ICP27 (12). Later, similar results were derived from the studying the regulatory roles of ICP 4 by using ICP 4 mutants (ts mutants, deletion mutants, and nonsense mutants), assayed by transfection or cotransfection experiments, or by detecting and comparing the different HSV mRNA betwcen wild types ICP4 and different kinds of mutated ICP4 $(6,7,8)$. Recently, Gu et al showed that the ICP4 autoregulatory function was related to the cellular protein $\mathrm{Spl}(26)$.

Another HSV-1 $\alpha$ gene essential for viral replication is the ICP27 gene. By using temperaturcsensitive (ts) mutants, Sacks et al showed that the growth of ICP27 ts mutants was markedly impaired at non-permissive temperature, and the expression of three class HSV-1 genes were altered (overexpression some of $\alpha$ genes and underexpression some of late genes) (59). These results indicated that ICP27 played an important regulatory function in HSV replication and it was required for the expression of HSV late genes. Later, the regulatory functions of ICP27 were revealed at both the transcriptional and post-transcriptional level $(39,55,61)$. Further study on the post-transcriptional regulatory role of ICP27 revealed that ICP27 could affect mRNA proccssing $(42,43,48,59,62)$, because its regulatory activity appeared to be promoter-independent and related to the mRNA processing signals present (62). In a system that used the TK (thymidine kinase) promoter sequence fused to different reporter genes, lacZ and CAT, Sandri-Goldin and Mendoza found that the ICP27 activity was related to the reporter gene structure, but not the promoter. They found that pTK-CAT was repressed 12-fold when cotransfected with ICP27, but there was no effect on pTK-lacZ (62). In agreement with this observation, Hardwicke and SandriGoldin demonstrated that when cells were infected with viral mutants defective in ICP27, the accumulated levels of at least three spliced host mRNAs were higher than those seen with wild-type 
infected cells (30). This suggested that the host shut off function of ICP27 might be due to an effect on cellular mRNA splicing.

In contrast to ICP4 and ICP27, ICP0 was demonstrated to be required, but not essential, for viral growth. This was based on the observation that ICP0 mutants of HSV-1 werc viable in cell culture, albeit more sluggishly than the wild-type (60). It has been shown in transient expression experiments that ICPO is the only one of all HSV-1 immediate-early proteins that was able to activate all three classes of HSV-1 genes $(15,16,22,19,54)$. The activation function of ICP0 can be performed either by itself alone, e.g. in the case of activation of HSV-1 ribonucleotide reductasc (RR1) gene (9), or in a synergistic manner with ICP4. However the activation function of ICP0 seems to be paradox, since in ICP4 mutants (wild type ICP0), the expression of HSV-1 carly and late genes is not activated $(6,12)$. This paradox may be explained by the requirement of ICP4 for the nuclear localization of ICP0 (72). In addition, ICPO has been thought to play an important rolc in the HSV-1 latency (68). Besides the functions of the three HSV-1 immediate-early proteins described above, these proteins are also involved in regulating the expression of certain cellular genes $(4,30,62)$.

\section{PREVIOUS WORK ON ACTIVATION OF c-MYC EXPRESSION BY HSV-1}

In 1992, Shin Chen et al reported a cellular regulatory protein, leaky-late binding factor (LBF) was involved in the activation of HSV-1 major capsid protein VP5 promoter. By using DNA footprint and sequence analysis, they found that the LBF target sequence, the leaky-late binding sequence (LBS), was very similar to that of a recently described cellular protein, YY1. Using competition electrophoretic mobility shift assay, they revealed that LBF and YY1 might be the same protein (4). Furthermore, using transient expression assays with HSV-1 superinfection or cotransfection of HSV-1 immediate-early proteins, they demonstrated that optimal transactivation of the VP5 promoter depended on an intact YYl binding site (4). Recently, Lisa Mills et al 
confirmed that LBF is the same protein as YY1 (47). These reports suggested that HSV-1 immediate-early proteins could activate HSV-1 leaky-late genes, such as the VP5 and gD genes through cellular factor YY1. On the other hand, YYl has been shown to be an activator of $c$-myc gene expression (57). From sequence analysis of the $c$-myc gene, several potential YYl binding sites were detected. One is located at downstream from the second promoter in the first $c$-myc exon (another one is located around $-240 \mathrm{bp}$ ). These observations led Dr. Millette to propose that HSV-1 infection might involved in activating $c$-myc expression. He and J. Paulson found: (i) The $c$-myc expression was activated by HSV-1 infection. (ii) HSV-1 treated with UV radiation failcd to transactivate $c$-myc expression (46). These results suggested that some products produccd by HSV-1 had a positive effects on the c-myc gene. Using cotransfection of HSV-1 immediate-early proteins, they showed that this transactivation was due to the HSV-1 immediate-early proteins, ICP4 and ICP0. ICP4 appeared to be the major transactivator, since when cotransfected with ICP4 only, the wild type CAT activity increased about 100-fold as compared with those that were non-cotransfected (46). An important observation linking c-myc regulation with HSV-1 infection from Dr. Millette laboratory's is that this regulation may be associated with the cellular protein E2F. The maps of the plasmids construction for the wild type (+66 wt-Myc-CAT) and mutant type (+66 mtE2F-Myc-CAT) are shown in Figure 1 . In the transient expression assay (CAT assay) for these plasmids, the CAT activity for E2F mutant plasmid decreased about 8.5-fold, comparing with that for the wild type plasmid, when superinfected with HSV-1. These results strongly suggested that $\mathrm{E} 2 \mathrm{~F}$ played an important role in transactivation of human $c$-myc gene expression by HSV-1 immediate-early proteins. This is in accord with the early observation that E2F plays an important role in the regulation of $c$-myc gene expression $(34,69)$.

\section{SCOPE OF THIS THESIS}

Early observations described above showed that (i) cellular regulatory protein YYl, in conjunction with HSV-1 immediate-early proteins, might activate the HSV-1 major capsid protein 
VP5 promoter (4); (ii) YYl is an activator for the $c$-myc gene expression (57); (iii) there is a potential YY1 binding site located at the downstream from the P2. Early studies also revealed that, in certain cases, regulatory elements located downstream from the promoter might be involved in affecting the promoter activity. Huang et al reported that the VP5 leader (the sequence at downstream from the VP5 promoter) is required for full-level expression by means of the scries deletion and transient expression assay (CAT assay) (35). Another report made by Guzowski et al also demonstrated that the downstream activation sequence (DAS), a 14 bp element locatcd at between +22 and +33 (from the transcriptional start site) in the 5 'untranslated leader region of the $\mathrm{U}_{\mathrm{L}} 38$ gene, was required for the full level of transcriptional activity of the $\mathrm{U}_{\mathrm{L}} 38$ (latc gcne) promoter (28). All these data led to the hypothesis that the region at the downstream from P2 in the $c$-myc exon 1 may be also important for the HSV-1 immediate-early protein-mediatcd $c$-myc regulation.

To test this hypothesis, the region in $c$-myc exon 1 downstream of the P2 was examined. First, the wild type $(-101 /+513-c-$ myc-CAT) and mutated plasmids $(-101 /+212-\Delta$ exon $1-c-$ myc-CAT and $-101 /+332-\Delta$ exon 1-c-myc-CAT) were constructed by following ways: (i) The $c$-myc sequcnces upstream of -101 (relative to $\mathrm{Pl}$ ), in the $c$-myc-CAT plasmids (in which the $c$-myc exon 1 was fused to the bacterial chloramphenicol acetyltransferase gene, CAT, were cut out by endonuclease digestion. (ii) The desired DNA fragments were isolated and ligated by DNA T4 ligation to generate $-101 /+513-c-$ myc-CAT and $-101 /+212-\Delta$ exon $1-c-$ myc-CAT. (iii) The sequences from +332 to +513 were cut out by endonuclease digestion of wild type $c$-myc plasmid $-101 /+513-c-$ myc-CAT. Then the desired large DNA fragment was ligated by using DNA T4 ligase, to generate $-101 /+332-\Delta$ exon $1-c-$ myc-CAT. Second, the regulatory roles of $c$-myc sequences downstream the $\mathrm{P} 2$ in exon 1 were assayed by HSV-1 superinfection, transfection of wild type or mutated $c$-mycCAT plasmids, and cotransfection of the plasmids containing HSV-1 immediate-early proteins 
gene. Third, DNA probes were prepared, and electrophoretic mobility shift assay (EMSA) or competition EMSA were performed to investigate the possibility that cellular proteins may be involved in this regulation. The results from these experiments suggested that DNA sequences located downstream from the P2 were important for regulation of $c$-myc gene expression by HSV-1 immediate-early proteins. In this regulation, ICP4 and ICP0 appear to function as activators and ICP27 as an inhibitor of gene expression. These results, combined with the data from early studies in both Dr.Millette's and other laboratories, suggest that the regulation c-myc gene by HSV-1 immediate-early proteins is mediated through cellular regulatory protein(s) which interact(s) with a cis-regulatory elements located downstream from the P2 start site within exon 1. 


\section{MATERIALS AND METHODS}

\section{PLASMID CONSTRUCTION (DELETION)}

(A) Construction and subcloning of plasmids $-101 /+212-\Delta$ exon 1-c-myc-CAT and $-101 /+513-c-$ myc-CAT.

\section{(1) STRATEGY OF CONSTRUCTION}

The plasmids $-2.3-\Delta$ exon $1-c-$ myc-CAT and $-1.3-c-$ myc-CAT, kindly provided as a gift from Nissim Hay of the Ben May Institute in Chicago, contain the upstream c-myc promoter element from the Pl transcription start site followed by an undeleted exon 1 or a deleted exon 1 linked to a reporter gene called chloramphenicol acetyltransferase (CAT). The plasmid maps and subcloning steps are diagrammed in Figure 2. Two $\mu \mathrm{g}$ of each of these two plasmids was digested by endonucleases Sma I and Cla I (7 units of each) in a final buffer concentration of 1X KGB [100 $\mathrm{mM}$ potassium glutamate, $25 \mathrm{mM}$ Tris-acetate $(\mathrm{pH} 7.5), 10 \mathrm{mM}$ magnesium acetate, $50 \mu \mathrm{g} / \mathrm{ul}$ bovine serum albumin Fraction V (Sigma), $1 \mathrm{mM} \beta$-mercaptoethanol] (61). The larger fragments from these two plasmids were isolated by the DEAE paper electroelution method which has been described previously (13). Briefly, the gel was cut at the site that was 3-4 mm in front of the DNA band, observed under the UV light following ethidium bromide staining. A piece of Whatman DEAE 81 paper that was slightly wider than the DNA band was inserted into the gel at the site that. was just in front of the DNA band. The DNAs were electroeluted onto the DEAE 81 paper by running the gel at 200 volts for about 20 minutes. The DEAE paper containing the plasmid DNAs was transferred into a $1 \mathrm{cc}$ syringe which was previously plugged by small amount glasswool. The DNAs on the DEAE paper were washed three times using $200 \mu$ leach time with solution A [0.1 N. $\mathrm{NaCl}, 0.1 \mathrm{mM}$ EDTA, and $10 \mathrm{mM}$ Tris- $\mathrm{HCl}(\mathrm{pH} 8.0)]$ by centrifugation each time at $1600 \mathrm{rpm}$ for 30 seconds. Then the DNAs were eluted three times using $120 \mu$ l for each time with solution B [I $\mathrm{M} \mathrm{NaCl}, 0.1 \mathrm{mM}$ EDTA, and $10 \mathrm{mM}$ Tris- $\mathrm{HCl}(\mathrm{pH} \mathrm{8.0)}$ ]. Finally, the DNAs were recovered by 
means of ethanol precipitation, and dissolved in $1 \mathrm{X}$ TE $[10 \mathrm{mM}$ Tris- $\mathrm{HCl}(\mathrm{pH} 8.0), 0.1 \mathrm{mM}$ EDTA].

In order to generate a blunt end at the Cla I site, $200 \mathrm{ng}$ of each two larger fragments was treated with 1 unit of Klenow fragment in a final buffer concentration of $1.5 \mathrm{X} \mathrm{KG \beta}$ in a total volume of $15 \mu \mathrm{l}(61)$. Following incubation for 30 minutes at RT, the four deoxyribonucleotides were removed by centrifugation through a $0.9 \mathrm{ml}$ Sephadex G-50 spun column (spun column chromatography). The column prepared in a $1 \mathrm{ml}$ syringe was equilibrated with TEN buffer [10 $\mathrm{mM}$ Tris- $\mathrm{HCl}(\mathrm{pH} \mathrm{8.0)}, 1 \mathrm{mM}$ EDTA (pH 8.0), $100 \mathrm{mM} \mathrm{NaCl}$, and it was prepared according to a procedure described previously (61). After the deoxynucleotides were removed, the fragments were recovered by ethanol precipitation. Finally about $100 \mathrm{ng}$ of each fragment, with blunted end at both ends, was ligated by incubation with 0.5 unit of T4 DNA ligase in 1X T4 DNA ligase buffer $[50 \mathrm{mM}$ Tris- $\mathrm{HCl}(\mathrm{pH} 7.6), 10 \mathrm{mM} \mathrm{MgCl}, 1 \mathrm{mM} \mathrm{ATP}, 1 \mathrm{mM}$ DTT, 5\% (w/v) polyethylene glycol-8000] in a total volume of $20 \mu$ incubated at $16^{\circ} \mathrm{C}$ for 24 hours. The purpose was to generate the new subclones, $-101 /+513-c$-myc-CAT and $-101 /+212-\Delta$ exon $1-c-$ myc-CAT, containing full-length or a deletion in exon 1. In generating these two subclones, the Sma I site and Cla I site were removed.

(2) TRANSFORMATION

Competent DM 1 cells, a strain of E.coli that lacks the EcoR I and Ava II methylases, were purchased from GIBCO BRL. The competent cells were transformed with the newly ligatec plasmids by the method provided by GIBCO BRL. According to this protocol, the transformatior was carried out as follows: For each plasmid, $50 \mu \mathrm{l} \mathrm{DM} 1$ cells and $3 \mathrm{ng}$ of plasmid DNA were mixed into a $1.5 \mathrm{ml}$ microfuge tube and incubated on ice for 30 minutes. The mixtures were give a heat-shock at $37^{\circ} \mathrm{C}$ (water bath) for 20 seconds, and were put on ice again for two minutes. Then the mixture were transferred into a clean $15 \mathrm{ml}$ polypropylene tube, and $0.95 \mathrm{ml}$ terrific brolh 
[ $1.2 \%$ bacto tryptone, $2.4 \%$ bacto yeast extract and $0.4 \%(\mathrm{v} / \mathrm{v})$ glycerol] was added. Then the transformed cells were incubated at $37^{\circ} \mathrm{C}$ by rotation. Finally, several dilutions of the transformed cells were plated onto LB plates $(100 \mu \mathrm{l}$ of the undiluted culture, $100 \mu$ l of a 10 times diluted culture, and $100 \mu \mathrm{l}$ of a 100 times diluted culture) and incubated at $37^{\circ} \mathrm{C}$ for 16 to 20 hours.

\section{(3) DNA EXTRACTION--- MINI AND MAXI PLASMID PREPARATION}

Mini plasmid preparation. The amplified plasmid DNAs (-101/+513-c-myc-CAT and $101 /+212-\Delta$ exon 1-c-myc-CAT were first extracted by a mini plasmid preparation method termed the "TENS" method. Briefly, $1.5 \mathrm{ml}$ of overnight culture, grown in the medium of LB containing ampicillin $(50 \mu \mathrm{g} / \mathrm{ml})$, was by sedimented centrifugation at high speed (about $10,000 \mathrm{rpm})$ at $4^{\circ} \mathrm{C}$ in a Hermle microcentrifuge. Most of supernatant was poured off (leaving 50 to $100 \mu \mathrm{l}$ ). The transformed cells were lysed by adding $300 \mu \mathrm{l}$ TENS solution $[10 \mathrm{mM}$ Tris- $\mathrm{HCl}(\mathrm{pH} 7.5), 1 \mathrm{mM}$ EDTA, $0.4 \% \mathrm{NaOH}$, and $0.5 \%$ (w/v) SDS]. Then the lysed cells were neutralized by adding 150

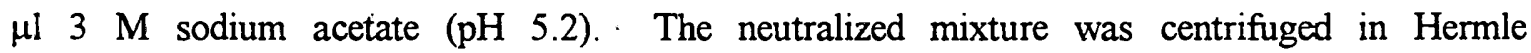
microcentrifuge at high speed (about $10,000 \mathrm{rpm}$ ) for 2 minutes at $4^{\circ} \mathrm{C}$. The supernatant containing the plasmid DNAs was transferred into a $1.5 \mathrm{ml}$ microfuge tube. The plasmid DNAs were precipitated by adding $0.9 \mathrm{ml} 100 \%$ ethanol, cooling the mixture to less than $-75^{\circ} \mathrm{C}$ in the Revco $-80^{\circ} \mathrm{C}$ freezer for 20 minutes, and the centrifugation in Hermle microcentrifuge at high speed (about $10,000 \mathrm{rpm}$ ) for 5 minutes at $4^{\circ} \mathrm{C}$. The supernatant was removed, and the DNA pellet was washed with $500 \mu 170 \%$ ethanol. Finally, the plasmid DNAs were dissolved in $30 \mu \mathrm{l}$ of IX TE

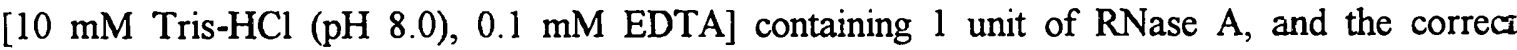
subclones were identified by restriction analysis and analytical agarose gel electrophoresis (se below)

Maxi plasmid preparation. All materials including resin columns (Qiagen-tip 500) and solutions were purchased from the Qiagen, Inc. Plasmid DNAs from large culture $(500 \mathrm{ml})$ we-e 
extracted by the Qiagen maxi plasmid preparation method according to the procedures described in the Qiagen plasmid handbook which was provided by Qiagen, Inc. Briefly, $500 \mathrm{ml}$ "Terrific Broth" [1.2\% bacto tryptone, $2.4 \%$ bacto yeast extract and $0.4 \%$ (v/v) glycerol] medium containing ampicillin $(50 \mathrm{ng} / \mathrm{ml})$ were inoculated with $5 \mathrm{ml}$ of overnight culture of the transformed $E$ coli cells (DM 1 or $\mathrm{HB101})$. These cells were grown with vigorous shaking $(280 \mathrm{rmm})$ at $37^{\circ} \mathrm{C}$. When they had reached an absorbency of 1 at $600 \mathrm{~nm}$ (for lower copy plasmids), chldramphenicol $(170 \mu \mathrm{g} / \mathrm{ml})$ was added to amplify plasmid DNAs and the culture was further incubated at $37^{\circ} \mathrm{C}$ with vigorous shaking $(280 \mathrm{rpm})$ for 12 to 16 hours. The cells were sedimented in a $250 \mathrm{ml}$ bottle) by centrifugation at $6,000 \mathrm{rpm}$ at $4^{\circ} \mathrm{C}$ for 15 minutes and they were resuspended with $10 \mathrm{ml}$ of Pl solution [100 mM $\mu \mathrm{g} / \mathrm{ml}$ RNase A, $50 \mathrm{mM}$ Tris/HCl, $10 \mathrm{mM}$ EDTA (pH 8. $)$ ]. Then the cells were lysed by mixing with $10 \mathrm{ml}$ of $\mathrm{P} 2$ solution ( $200 \mathrm{mM} \mathrm{NaOH}, 1 \% \mathrm{SDS}$ ). Affer standing 5 minutes on ice, the lysate was neutralized by adding $10 \mathrm{ml}$ of $\mathrm{P} 3$ solution [3.0 M KAc (pH 5.5)]. Cellular debris and $E$ coli genomic DNA were removed by the centrifugation in the Sorvall centrifuge at $13000 \mathrm{rpm}$ at $4^{\circ} \mathrm{C}$ for 30 minutes. Plasmid DNAs were separated from proteins and RNAs by passing the supernatant solution through a resin column called Qiagen-tip 500 . The DNAs were eluted from the column by adding $15 \mathrm{ml}$ of QF buffer $(1.25 \mathrm{mM} \mathrm{NaCl}, 50 \mathrm{mM}$ Tris/ $\mathrm{HCl}, 15 \%$ ethanol,). The eluted DNAs were precipitated with isopropandl (see Qiagen plasmid handbook for detail). Finally, the extracted DNAs were dissolved in 400 to $500 \mu \mathrm{l}$ of $1 \mathrm{X}$ TE and they were analyzed by restriction analysis and agarose gel electrophoresis. The correcı subcloned plasmids were kept at $4^{\circ} \mathrm{C}$. The concentration and total yields of extracted plasmid: were measured by calculating their absorbency at $260 \mathrm{~nm}, 280 \mathrm{~nm}$, and $320 \mathrm{~nm}$ in the Beckman DU-40 spectrophotometer.

\section{(4) SELECTING SUBCLONES BY RESTRICTION ANALYSIS}

The enzymes used in the restriction analysis were purchased from GIBCO BRL and Ne= England Biolabs. The extracted subcloned DNAs from both mini and maxi plasnid preparations 
were checked by the restriction analysis. Briefly, the plasmid DNAs were cleaved witr. restriction enzymes (endonucleases) so that the circular plasmid DNAs were cut into one linear fagment, or two or three linear fragments. They were also incubated with enzymes which were not able to cleave this specific kind of the plasmid DNA (e.g. in the subcloned plasmids $-101 /+513-c-$ mycCAT and -101/+212- $\Delta$ exon 1-c-myc-CAT, the Sma I and Cla I sites were removed, so Sma I and Cla I were not able to cleave these two plasmids). These fragments, as well as the uncut plasmid, were electrophoresed in an agarose gel (gel concentrations depended on the sizes of the fragments) using $0.5 \mathrm{X}$ TBE $(0.54 \%$ Tris base, $0.28 \%$ boric acid, $1 \cdot \mathrm{mM}$ EDTA) as the gel rurning buffer. DNA fragments with the known sizes, e.g. $\lambda /$ Hind III, were used as size markers in the same gel (when the bacteriphage $\lambda$ digested by endonuclease Hind III, several known size DNA fragments, such as $23.1 \mathrm{kbp}, 9.4 \mathrm{kbp}, 6.68 \mathrm{kbp}, 4.36 \mathrm{kbp}, 2.3 \mathrm{kbp}, 2.1 \mathrm{kbp}$, and $0.56 \mathrm{kbp}$, were generated). After electrophoresis, the gel was stained by ethidium bromide $(0.5 \mu \mathrm{g} / \mathrm{ml})$ for about 16 minutes, and photographed with the Polaroid film No.667 under the transmitted UV light using a UV transilluminator. The distances of the marker fragments run in the agarose gel were measured, and a standard curve, which represented the relationship between fragments sizes and distances, was plotted on semi-log paper according to the sizes and distances of the marker fragments. The sizes of the sample fragments were determined by measuring the distances of the sample fragments run in the gel, and then pointing the distances values on the standard curve.

(B) Subcloning for plasmid -101/+332- exon 1-c-myc-CAT.

The plasmid map and subcloning steps are diagrammed in Figure 3. Two $\mu \mathrm{g}$ of the plasmid 101/+513-c-myc-CAT was digested with the endonucleases Hind III and Xho I (eacin of 7 units) ir a final buffer concentration of $1 \mathrm{X} \mathrm{KGB}$ in a total volume of $30 \mu \mathrm{l}$ for 3.5 hours at $37^{\circ} \mathrm{C}$. The larger fragment, the Hind III-Xho I fragment which would be used as the vector, was isolated b: the electroelution onto a dialysis membrane (dialysis membrane method) (45). Briefly, a slo*, 
which was slightly wider than the width of the band (DNA fragment being isolated), was made just 3 to $4 \mathrm{~mm}$ in front of the band in the ethidium bromide stained agarose gel. The Hind III-Xho I fragment was run onto a piece of nitrocellulose dialysis membrane (whether the DNAs were completely run onto the membrane need to be checked under the UV light) in a $1 \%$ agarose gel at 200 volts for about 20 minutes. The fragment was removed from the dialysis membrane by running the gel at 200 volts for about 1.4 minutes in the direction opposite to the original gel running direction. The DNAs in the slots were collected by pipetting them into a $1.5 \mathrm{ml}$ microfuge tube and recovered by ethanol precipitation. Then $100 \mu \mathrm{g}$ of the plasmid $-101 /+513-\Delta$ exon $1-c-$ myc-CAT were digested again with the endonucleases Hind III and Xho I (each of 350 units) in a final buffer concentration of $1 \mathrm{X} \mathrm{KGB}$ in a total volume of $550 \mu \mathrm{l}$ for 4 hours at $37^{\circ} \mathrm{C}$. The smaller fragment, the $487 \mathrm{bp}$ Xho I-Hind III fragment (from the Xho I site to Hind III site) was isolated by the dialysis membrane method as described above. This fragment (about $2.5 \mu \mathrm{g}$ ) was further digested by endonuclease of Ava II (10 units) in a final buffer concentration of $1 \mathrm{X} \mathrm{KGB}$ in a total volume of $30 \mu \mathrm{l}$ for 3.5 hours at $37^{\circ} \mathrm{C}$ to generate three fragments: a $266 \mathrm{bp}$ Xho I-Ava II fragment, a 151 bp Ava II-Ava II fragment, and a 71 bp Ava II-Hind III fragment. All three fragments were isolated by means of dialysis membrane method as described above. Then $200 \mathrm{ng}$ of the Hind III-Xho I fragment (as a vector) and $30 \mathrm{ng}$ of the $266 \mathrm{bp}$ Xho I-Hind III fragment were ligated by using 1 unit of T4 DNA ligase. In order to generate the blunt ends at the Ava II and Hind III sites, the ligated mixture was treated with Klenow fragment as described above. After the Klenow fill-in reaction, the deoxynucleotides were removed by passing through a G-50 column as described above (61). The new subclone, $-101 /+332-\Delta$ exon $1-c-$ myc-CAT, was generated by ligating both blunt ends of the fragment with 1 unit of T4 DNA ligase incubated at 37C for 24 hours. In this subcloned plasmid, both the Ava II site and Hind III site were removed.

The transformation, DNA extraction and restriction analysis processes were the same a: described above except that the strain of competent cells used in the transformation was HB 101, 
another strain of $E$ coli, instead of DM 1, and the endonucleases used in restriction analysis (see table 4).

\section{DNA PROBE PREPARATION}

Three DNA fragments from $c$-myc exon 1, the 266bp Xho I-Ava II fragment, the $151 \mathrm{bp}$ Ava IIAva II fragment, and the $71 \mathrm{bp}$ Ava II-Hind III fragment, were isolated as described above. These three fragments were labeled with $\alpha-{ }^{32} \mathrm{P}-\mathrm{dATP}$ and $\alpha-{ }^{32} \mathrm{P}-\mathrm{dCTP}$ by means of Klenow fill-in reaction (see Fig.4) which was described previously (61). Briefly, each of being labeled fragment was mixed with radioactive deoxynucleotides (labeled with $\alpha-{ }^{32} \mathrm{P}-\mathrm{dATP}$ and $\alpha-{ }^{32} \mathrm{P}-\mathrm{dCTP}$ ), nonradioactive deoxynucleotides (dGTP and dTTP), and 1 unit of Klenow enzyme. The reaction mixture was incubated for 20 minutes at room temperature (RT). Then the reaction mixture was chased with $1 \mathrm{mM}$ of each four unlabeled deoxynucleotides for 10 minutes at RT. The Klenow fragment activity was inactivated by heating the mixture at $70^{\circ} \mathrm{C}$ for 10 minutes. The $\alpha-{ }^{32} \mathrm{P}-$ labeled or $\alpha-{ }^{32} \mathrm{P}$-unlabeled deoxynucleotides were removed by passing the reaction mixture through a G-50 spun column.. The $\alpha-{ }^{32}$ P-labeled fragments (probes) were recovered by ethanol precipitation and were dissolved in $100 \mu \mathrm{l} 1 \mathrm{X} \mathrm{TE}$ and stored at $-20^{\circ} \mathrm{C}$. The radioactivities of the $\alpha-{ }^{32}$ P-labeled probes were determined in a Beckman LS6500 liquid scintillation spectrometer.

\section{CELLS AND VIRUS}

Cells and virus used and their propagation were described in the previously published paper by Chen et al (4). Briefly, Hela cells (ATCC CCL2) maintained at $37^{\circ} \mathrm{C}$ under $5 \% \mathrm{CO}_{2}$ atmosphere in Dulbecco's modified Eagle medium (DMEM; GIBCO Laboratory Inc.) supplemented with 10\% (v/v) heat-inactivated fetal bovine serum, penicillin $(100 \mathrm{u} / \mathrm{ml})$, and streptomycin $(100 \mathrm{u} / \mathrm{ml})$. The virus, kindly provided by G.S.Read, Loyola, University of Chicago, was the vsh-1 mutant of HSV1 (KOS) which was defective in the first stage host shutoff function and it was previously propagated in HEp-2 cell monolayers by Dr. Millette in the Biology Department of Portland State 
University.

\section{TRANSFECTION, COTRANSFECTION AND HSV-I SUPERINFECTION}

The procedures for transfection, cotransfection and HSV-1 superinfection were almost same as described in the previously published article $(24,25,50)$ modified by Chen et al $(4)$, except that in the cotransfection assay, the amounts of each plasmid DNA, encoding for HSV-1 immediate-early proteins (ICP0, ICP4, ICP27), were $2 \mu \mathrm{g}$ instead of $8 \mu \mathrm{g}$ (the plasmid pUCl8 was used to adjust the total amount of DNAs to $16 \mu \mathrm{g}$ which represented the total amount of different kinds of plasmis in one well). Briefly, Hela cells were seeded in $35-\mathrm{mm}$ well cluster dishes at $3 \times 10^{5}$ cells per well in $3 \mathrm{ml} \mathrm{DMEM-10 \%} \mathrm{IFBS-P/S} \mathrm{(4),} \mathrm{and} \mathrm{incubated} \mathrm{at} 37^{\circ} \mathrm{C}$ in the presence of $5 \% \mathrm{CO}_{2}$. Twenty hours later, the plasmid DNAs were precipitated by a procedure called calcium phosphateprecipitation. Briefly, for each duplicate, the appropriate mount of plasmid DNAs being transfected or cotransfected was mixed with $0.5 \mathrm{ml}$ of $2 \mathrm{X}$ HEPES-buffered saline (HES) (280 mM $\mathrm{NaCl}, 10 \mathrm{mM} \mathrm{KCl}, 1.5 \mathrm{mM} \mathrm{Na} \mathrm{HPO}_{4}, 12 \mathrm{mM}$ dextrose, $50 \mathrm{mM}$ HEPES) in a $5 \mathrm{ml}$ polypropylene tube. Then $0.5 \mathrm{ml}$ of $0.25 \mathrm{M} \mathrm{CaCl}_{2}$ was added dropwisely with bubbling and the adding of $\mathrm{CaCl}_{2}$ took about 15 seconds. The mixture was incubated at RT for 30 minutes. Then $0.5 \mathrm{ml}$ of calcium phosphate-precipitated DNA was transfected (plasmid DNAs containing full length of $c$-myc exon 1 or deletions in the $c$-myc exon 1) or cotransfected (plasmid DNAs containing HSV-1 immediateearly genes) into Hela cells. Four hours after transfection or cotransfection, the medium was removed and the cells were shocked by $1 \mathrm{ml}$ glycerol shock solution $[15 \%$ (v/v) glycerol in DMEM-10\% ICFS] for 1 minute. The cells then were washed 2 times with $3 \mathrm{ml}$ PBS-A (0.14 M

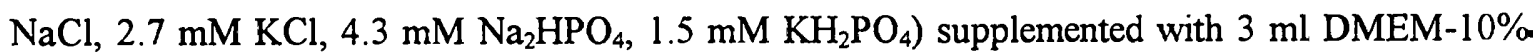
IFBS-P/S, and further incubated at $37^{\circ} \mathrm{C}$ under $5 \% \mathrm{CO}_{2}$. Twenty hours after the transfection or cotransfection, the transfected cells were superinfected with HSV-1 (described in cells and virus) at multiplicity of infection of 3 . At the meantime, the mediums for the cotransfected cells were 
changed (renewed with the same medium). Both transfected and cotransfected cells were harvested 40-44 hours after the transfection or cotransfection. The cells superinfected by HSV-1 were checked under the microscope, and were harvested when they were approximately $40-50 \%$ rounded even the time was less than 40 hours. The harvested cells were lysed by the method perfomed by Nordeen et al (50) Briefly, the cells in each well were rubbed off from well by using a "rubber policeman", and were sedimented by centrifugation in a Hermle microcentrifuge at lower speed at $4^{\circ} \mathrm{C}$ for 3 minutes. The supernatant was removed by aspiration. Then the cells werre lysed by resuspending them in $100 \mu$ lysis buffer $[0.25 \mathrm{M}$ Tris/ $\mathrm{HCl}(\mathrm{pH} 7.8), 0.25 \%(\mathrm{v} / \mathrm{v}) \mathrm{NP}: 40,0.005 \%$ (w/v) PMSF], mixing them well, and incubating them on ice for 10 minutes. The mixture was centrifuged in the Hermle microcentrifuge at lower speed at $4^{\circ} \mathrm{C}$ for 5 minutes. Finally the supernatant (lysate) was transferred into a clean $1.5 \mathrm{ml}$ microfuge tube, and the lysates were kept at $-80^{\circ} \mathrm{C}$ (in Revco) for CAT assay.

\section{CAT ASSAY}

The CAT assay was described previously $(4,50)$, and it consisted of measuring incorporation of ${ }^{3} \mathrm{H}$-acetate (NEN Research Products, Inc.; $3.3 \mathrm{Ci} / \mathrm{mmol}, 10 \mathrm{mCi} / \mathrm{ml}$ ) into acetyl-chloramphenicol by using a coupled reaction with acetyl coenzyme A synthetase $(4,50)$. Briefly, for each reaction, $43 \mu \mathrm{l}$ of distilled water, $31.5 \mu \mathrm{l}$ of $4 \mathrm{X}$ CAB [4X CAT assay buffer (400 mM Tris-HCl pH 7.8, 24 $\mathrm{mM} \mathrm{MgCl} 2$, and $300 \mathrm{mM} \mathrm{KCl})],{ }^{3} \mathrm{H}$-labeled acetyl acid $(0.78 \mu \mathrm{Ci} / \mu \mathrm{l}), 10 \mu \mathrm{l}$ of $5 \mathrm{mM}^{\prime}$ Coenzyme A, $4 \mu \mathrm{l}$ of $100 \mathrm{mM}$ ATP, and $0.5 \mu \mathrm{l}$ of $250 \mathrm{mM}$ chloramphenicol were mixed in a $1.5 \mathrm{ml}$ microfuge tube and pre-incubated for 30 minutes at $37^{\circ} \mathrm{C}$. Then $30 \mu \mathrm{l}$ of each sample lysate was added to each tube and the contents were incubated at $37^{\circ} \mathrm{C}$ for 2 hours. After the incubation, $1 \mathrm{ml}$ of cold benzene was added to each reaction tube, and the contents were completely mixed by vigorous vortexing and inverting. This mixture was centrifuged in Hermle microcentrifuge at high speec (about $10^{4} \mathrm{rpm}$ ) for 2 minutes at $4^{\circ} \mathrm{C}$. After centrifugation, $800 \mu$ l solution from the benzene phase 
was transferred into a scintillation vial and dried by evaporation. Finally, the radioactivities of acetyl chloramphenicol (cpm) was measured in a Beckman liquid scintillation spectrometer. The net cpm of acetyl chloramphenicol for each sample was obtained by subtracting the cpm of the control plasmid (e.g. pUC18) which does not contain the CAT gene.

\section{ELECTROPHORETIC MOBILITY SHIFT ASSAY (EMSA)}

Both HSV-1 uninfected and HSV-1 infected nuclear extracts (NE) were previously prepared by Dr.Millette (in Biology Department of PSU) according to the procedures performed by J. D. Dignam et al (23). In each reaction, NE containing $2 \mu \mathrm{g}$ of protein, DNA probe $\left(10^{4} \mathrm{cpm}\right), 1-2$ $\mathrm{mM} \mathrm{MgCl}$, and $1 \mu \mathrm{g}$ polydIdCpolydIdC (double stranded polydIdC) (Pharmacia Biotech) were mixed in $0.65 \mathrm{ml}$ microfuge tube. The binding reaction was taken place at RT for 20 minutes in a total volume of $16 \mu \mathrm{l}$. Then $1.6 \mu$ of $10 \%$ bromophenol blue (BPB) was added. A $4 \%$ polyacrylamide gel (PAGE), which was pre-run at 250 volts at $4^{\circ} \mathrm{C}$ for about 60 minutes, was used for electrophoresis. The running buffer used in this experiment was $1 \mathrm{X}$ NRB $[0.3 \%(\mathrm{v} / \mathrm{v})$ Tris base, $1.43 \%(\mathrm{w} / \mathrm{v})$ glycine, $10 \mathrm{mM}$ EDTA]. The samples were electrophoresed at 250 volts at $4^{\circ} \mathrm{C}$ for 130 minutes. Then the gel was transferred onto a piece of $3 \mathrm{~mm}$ paper, covered with a piece of plastic food wrap, and put on a gel slab dryer for 2 hours to dry. The dried gel was covered by a RX Fuji film $(20.3 \times 25.4 \mathrm{~cm})$ which then was exposured for about 13 hours at $-80^{\circ} \mathrm{C}$. The film was developed and analyzed for protein binding.

\section{COMPETITION EMSA}

Competition EMSAs were run similarly to the EMSA, except that an additional unlabeled $33 \mathrm{bp}$ dsDNA oligonucleotide, whose sequence is CCAGGATCCAGGGCCATCTTGAATGGATCCTGG, was added. This oligonucleotide was named LBS (4) was synthesized by Vollum Institute, Oregon Health Sciences University. It contained a binding site for nuclear protein YYl, shown in the underlined part of the sequence $(4,47)$. The control probe used in this assay was the ${ }^{32} \mathrm{P}$ - 
labeled 160 bp DNA fragment from VP5 (HSV-1 major capsid protein) promoter, which was previously shown to contained the sequence for the cellular protein YYI binding. 


\section{RESULTS AND CONCLUSIONS}

\section{RESULTS}

(1) Preparation and analysis of subclones $-101 /+513-c-$ myc-CAT and $-101 /+212-\Delta$ exon 1-c-myc-CAT.

To determine whether the sequences in the first exon from $\mathrm{P} 2$ are important for the activation of $c$-myc gene expression by HSV-1, the plasmids containing deletions in exon 1 of the $c$-myc gene were constructed (see Fig. 2). First, plasmids containing only 101 bp upstrcam of the $c$-myc promoter were prepared by excising the region from $-2.3 \mathrm{kbp}$ to $-101 \mathrm{bp}$ in the plasmid $-2.3-\Delta$ exon 1-c-myc-CAT, and the region from -1.3 to -101 in the plasmid $-1.3-c-$ myc-CAT (both plasmids were the gifts from the Nissim Hay in Ben May Institute in Chicago) by digestion with restriction endonucleases Sma I and Cla I. The large vector fragment was isolated by the DEAE paper electroelution method. The blunt ends were made at the $\mathrm{Cla}$ I site of the vector fragments by the Klenow fill-in reaction. The two vector fragments were then ligated using T4 DNA ligase to generate plasmids $-101 /+513-c-$ myc-CAT (used as a wild type control) and $-101 /+212-\Delta$ exon $1-c$ myc-CAT. Then the subcloned plasmids were transformed into competent $E$ coli cells, screened by mini plasmid preparation. The correct subcloned plasmid DNAs were extracted by maxi plasmid preparation. The total yields from a $500 \mathrm{ml}$ culture was 292 ug for $-101 /+513-c$-myc-CAT and 304 ug for $-101 /+212-\Delta$ exon $1 c$-myc-CAT.

The resulting plasmids were examined by restriction analysis (see Fig.5 for restriction map). First, both $-101 /+513-c-m y c-C A T$ and $-101 /+212-\Delta$ exon 1-c-myc-CAT were digested by endonuclease Hind III, Hind III/Pvu I, EcoR I, and Sma I/Cla I. The digesting mixtures were run in a $1 \%$ mini gel (Fig. 10). The mini gel showed that the number of observed bands resulted from this digestion is consistence with the number of expected bands (Table 1), and the sizes of observed 
bands are approximately estimated to be correct according to the sizes of marker bands (sizes can not be accurately measured in mini gel) (Fig.10). To confirm the mini gel results, these two subcloned plasmids were examined in two standard agarose gels, $0.9 \%$ gel for linear form and $1.2 \%$ gel for diagnostic digestion (most important evidence) by EcoR I and EcoR I/Nol 1 (Fig. 13 and Table 2). These results indicated that both sizes and numbers of the bands produced coincided with those expected from restriction maps. Therefore they appeared to be the correct subcloncs. To confirm the deletion part of the subclone $-101 /+212-\Delta$ exon $1-c-m y c-C A T$, DNA scquencing was carried out. Although part of sequences upstream the Nea I site $(+212 \mathrm{bp})$ could be read, it failed to show the deletion part. Therefore an alternative experiment, the restriction analysis of a small fragment [from Not I site $(+22)$ to Hind III site] spanning the deletion part, was performed. Thus the Not I-Hind III fragment (see Fig.5) was isolated and further analyzed the digcstion of endonucleases Pvu II, Alu I, Xho I, Hinf I, Ava I and Ava II. This analysis showed that this fragment was able to be digested by Xho I only, and it could not be digested by Pvu II, Alu I, Hinf I, Ava I and Ava II (Fig.11). This result was consistent with the data shown on the plasmid map (see Fig.5), from Nissim Hay in Ben May Institute in Chicago (32), and confirmed that the $101 /+212-\Delta$ exon 1-c-myc-CAT was the correct subclone.

(2) Preparation and analysis of subclone $-101 /+332-\Delta$ exon 1-c-myc-CAT

To further determine the more specific region within the $c$-myc exon 1 which was responsible for HSV-1 immediate-early proteins mediated human $c$-myc regulation, the region from +332 to +513 (181 bp), and the adjacent $40 \mathrm{bp}$ up to Hind III site in the plasmid $-101 /+513-c-\mathrm{mpc}-\mathrm{CAT}$ was removed by the endonucleases Ava II and Hind III as described above. The subclone -101/+332$\Delta$ exon 1-c-myc-CAT was generated by first ligating the vector with the $266 \mathrm{bp}$ Xho I- Ava II fragment by T4 DNA ligase (see Fig. 3), treating Klenow fragment to make both ends blunt, finally ligating both blunt ends together with T4 DNA ligase. 
The plasmid DNAs of this subclone were prepared by the Qiagen maxi plasmid preparation method (as described above). The total yield from a $500 \mathrm{ml}$ culture was $360 \mathrm{ug}$. As with the other subclones, this subclone was examined by restriction analysis with the endonucleases Hind III, EcoR I, Not I, and Xho I (see Fig.5 for the restriction map) first in a 1\% mini agarose get (Fig. 12). The mini gel results showed that the number of observed bands is consistence with the number of expected bands (Table 1). In Fig. 12, it also showed that the sizes of the bands are approximatcly measured to be correct according to the sizes of marker bands (the accurate size can not be measured in mini gel). To confirme the mini gel results, this plasmid was examined in two different concentration standard agarose gel, $0.9 \%$ for linear form and $1.2 \%$ for diagnostic restriction (most important evidence). The standard gel is shown in (Fig.10 and 13) and the sizes of bands in standard gel were measured (Table 2). The results (shown in Table 1, Table 2, Fig. 10, Fig. 12, and Fig.13) indicate that both sizes and numbers of the bands agree with those predicted from the restriction map. Therefore $-101 /+332-\Delta$ exon $1-c-$ myc-CAT subclone is correct.

(3) Sequences located at downstream from the P2 in the $c$-myc exon 1 contain the responding elements for the ICP4 and ICPO mediated activation

To determine whether there is a element located downstream from the start site in the $c$-myc gene, P2, which is activated by HSV-1 immediate-early proteins, the subcloned plasmids 101/+513-c-myc-CAT (as wild type control containing - 101 to +513 of $c$-myc ) and $-101 /+212-$ $\Delta$ exon I-c-myc-CAT (containing -101 to +212 of the $c$-myc) were assayed separately two times in a transient expression assay system (CAT assay). The linear maps are shown in Figure 5. To test their abilities to be transactivated by HSV-1, the HeLa cells were transfected with each of these plasmids, and 20 hours later they were superinfected with HSV-1 at a multiplicity of 3 . Parallel control cultures remained HSV-1 unsuperinfected. Twenty to twenty four hours after superinfection the cells were harvested and their lysates were analyzed for CAT enzyme activity. 
The results are shown in the Figure 6 and the Table 3. These results showed that the CAT activity increased 5.7-fold for the wild type $c$-myc plasmid -101/+513-c-myc-CAT when HSV-1 was superinfected. Similarly, a 3.9-fold and a 1.9-fold increase were observed in the mutanf (deletion in the first exon of $c$-myc) $c$-myc plasmids $-101 /+212-\Delta$ exon $1-c$-myc-CAT and $-101 /+332-\Delta$ exon 1-c-myc-CAT, respectively. Furthermore, when the CAT activity was compared to that of the wild type $-101 /+513-c-$ myc-CAT in the presence of HSV-1 superinfection, a 5.2-fold and a 6.2 -fold reduction was observed in the cells transfected with the mutant $c$-myc plasmids $-101 /+212-\Delta$ exon 1-c-myc-CAT and -101/+332-Aexon 1-c-myc-CAT, respectively. When compared to the wild-type level set at $100 \%$, the represented relative CAT level of $19.2 \%$ and 16.1 to the $-101 /-212$ and 101/+332 deletion respectively (Fig.6, Table 3). These results were accord with the previous data from Dr. Millette's laboratory that c-myc gene expression was strongly activated by HSV-1 infection, and they indicated that the sequences within the first exon of $c$-myc gene are important for activation by HSV-1 infection.

According to previous results from this laboratory (46), the major activation is provided by HSV-1 immediate-early proteins ICP4 and ICP0. To investigate the involvement of sequences in the +332 to +513 bp region in this activation, the activity of the subclone $-101 /+332-\Delta$ exon $1-c-$ myc-CAT was compared with that of the wild-type promoter in two separate cotransfection assays. One reason to speculate the region from +332 to +513 of the first exon of $c$-myc is important for the ICP4 and ICP0 mediated activation is that it contains a potential binding site for the cellular regulatory protein $\mathrm{YYl}$ at about $+453 \mathrm{bp}$. This cellular regulatory protein was previously shown to be involved in activating the murine $c$-myc promoter (57) and the HSV-1 VP5 promoter (4). To investigate this, HeLa cells were transfected with wild type and exon 1 deletions of $c$-myc-CAT, and simultaneously cotransfected with plasmids expressing HSV-1 IE proteins it contains. The results of the cotransfection assays (see Fig.7 and Table 4) demonstrate that, comparing with the 
non-cotransfected cells (transfected with $-101 /+513-c-$ myc-CAT only), the CAT activatics of the wild type $c$-myc plasmid -101/+513-c-myc-CAT increased 13.7-fold when cotransfected with ICP4, 16.7-fold when cotransfected with ICP4 and ICP0, and it was reduced 1.5-fold when cotransfected with ICP4, ICP0, and ICP27. Relative to the wt $(-101 /+513)$ set at $100 \%$, cotransfection of ICP4 alone was $78.3 \%$, and ICP4, 0, and 27 was $5 \%$. On the other hand, the similar comparison in the c-myc mutated plasmid showed that the CAT activity of the plasmid 101/+332- $\Delta$ exon 1-c-myc-CAT increased 2.1-fold when cotransfected with ICP4, and 4.5-fold when cotransfected with ICP0, and it was reduced 1.1-fold when cotransfected with all three HSV1 immediate-early proteins. Relative to the wt CAT plasmid induced with ICP4/ICP0 (as $100 \%$ ), this deleted plasmid $(-101 /+332)$ gave the CAT level of $2.5 \%, 16.0 \%$, and $0.9 \%$ when cotransfected with ICP4, ICP4/ICp0, and ICP4/ICP0/ICP27, respectively. These results lead to two suggestions: (i) The region from +332 to +513 contains an element required for $c$-myc gene activation by HSV-1 immediate-early proteins. (ii) ICP4+ICP0 together providz maximum transactivation, ICP4 appears to provide the major, single transacting effect, and ICP27 functions to inhibit its expression.

(4) Are there any binding sites for cellular regulatory proteins in the region from +332 to +513 in the first exon of $c$-myc gene?

To determine whether any cellular regulatory protein(s) bind(s) to the $c$-myc exon 1 region between +66 and $+513 \mathrm{bp}$, electrophoretic mobility shift assays were carried out with three $c$-myc fragments spanning this region. These fragments were 266 bp Xho I-Ava II fragment [from +66 bp to +332 bp (see Fig. 5)], 151 bp Ava II-Ava II fragment [from +332 bp to +483 bp (see Fig. 5)], and $71 \mathrm{bp} \mathrm{Ava} \mathrm{II-Hind} \mathrm{III} \mathrm{fragment} \mathrm{[from}+487 \mathrm{bp}$ to $+513 \mathrm{bp}$, and up to Hind III site at the start site of the CAT gene (see Fig. 5)]. Because of the data derived from CAT assay, we emphasized examining the region from +332 to +513 in the $c$-myc exon 1 . The results of the- 
EMSA (Fig.8) showed: (i) There are two major shift bands observed in the lanes for the $266 \mathrm{bp}$ Xho I-Ava II probe (Fig.8, lane 11 and 12). (ii) There were three shifted bands (two major bands and one minor band) observed both for the $151 \mathrm{bp}$ Ava II-Ava II probe which contains 3 potential binding site for transcription factor YYl (Fig.8, lane 6 and 7), and 71 bp Ava II-Hind III probe (lane 2 and 3). Previous studies have shown that HeLa cell nuclear extracts form 2 bands with YY1, one representing a YY1 degradation product (4). Therefore two of these bands could be caused by YY1. To determine if any of these bands were formed by YY1, the competition EMSAs were carried out. The results showed (Fig.8): (i) Positive control probe (VP5) has two clear bands caused by YYl binding. They appear to be lowered in intensity when the LBS is present. (ii) The bands observed in the 266 bp probe are only slightly competed. (iii) The intensity of these bands did not diminished when the radioactive 151 bp Ava II-Ava II probe was competed with a 200-and 400-fold molar excess of LBS, a unlabeled $33 \mathrm{bp}$ dsDNA fragment containing a YY1 binding site (Fig.8, lane 8 and 9). This indicated that these shifted bands were not due to the YYY binding. (iii) Three bands (two major bands and one minor band) were observed when $71 \mathrm{bp}$ probe was used. The two major shifted bands disappeared when competed with a 400 -fold molar excess of LBS, indicating that these bands were due to binding of the cellular regulatory protein, YYl (Fig.8, lane 4). This observation was confirmed by early data from competition EMSAs using ${ }^{32}$ P-labeled 222 bp Ava II-Hind III fragment (from the Ava II site at +332 within $c$-myc exon I to Hind III site, and see Fig.5 for map). In this experiment, C2, a dsDNA fragment not containing YY1 binding site, was used as a negative control oligonucleotide. The results showed that the two bands supposed to be caused by YYl binding diminished when the 222 bp Ava II-Hind III probe was competed with LBS, but they did not diminished when the probe was competed with C2 (Fig.9). Thus, the possibility that the two bands were caused by non-specific proteins binding was excluded. However, from the sequence analysis, there was no YY1 consensus binding sites to be 
found in this region, indicating that YY1 was not a factor involved in HSV-1 immediate-early proteins mediated regulation of human $c$-myc gene. This looks like somewhat contradictory. There are two possible explanations: (i) the 40 bp vector sequence (see Fig.5) constructed by Hay contains a YYl binding site; (ii) the region from +483 to +513 might contain a non-consensus or high degenerated YYl binding site. According to the second explanation, the role of the cellular protein YYl in the HSV-1 immediate-early proteins mediated $c$-myc regulation still could not excluded.

\section{CONCLUSION}

The results from these studies lead to the follow conclusions:

(1) HSV-1 immediate-early proteins are regulators for human $c$-myc gene expression in transient assays. ICP4 is the major transactivator, ICP0 is a minor transactivator, and ICP27 serves as an inhibitor of the $c$-myc gene expression.

(2) The region from +332 to +513 in the exon 1 of the $c$-myc gene contains a sequence which is responsible for the ICP4 and ICP0 mediated transactivation of human c-myc gene expression [other important regions upstream of the P2, such as E2F site, were also identified in previous studies (46)].

(3). The data from my EMSA results suggest that at least one cellular regulatory protein is involved in viral regulation of the human $c$-myc gene through sequences in exon 1 .

(4). From the data derived from the EMSA and competition EMSA, I conclude that the cellular regulatory protein YY1 is not likely involved in the HSV-1 mediated regulation of human $c$-myc gene through the exon 1 sequences. However, there is a possibility that a non-consensus YYl binding site may be involved for the regulation by this region of the $c$-myc gene. 


\section{DISCUSSION}

Early studies revealed that $c$-myc expression is regulated, either positively or negatively, by many factors at different stages (e.g. it may be regulated at level of initiation of transctiption or at level of elongation of transcription). Many target sequences for cellular transcription factors have been identified in the c-myc promoter in the region between $2.3 \mathrm{kbp}$ and the transqription start sites, P1 and P2 (10, 33). Recently Dr. Millette and J. Paulson found that HSV-1 immediate-early proteins (mainly ICP4) could activate the expression of $c$-myc gene (46). Their stadies further showed that this activation was related to a target sequence for cellular protein E2F binding. This binding site was located between P1 and P2 (around +117) (46). Consistant with the results shown by Millette and Paulson, the experiments presented here also demonstrate that the human $c$-myc gene is regulated by the HSV-1 immediate-early proteins. In these experiments, additional target sequences for HSV-1 immediate-early proteins (ICP4 and ICP0) mediated activation is identified in the region downstream from P2 (between +332 and $+513 \mathrm{bp}$ ), within the first exon of the $c$-myc gene. The exact mechanism involved in this regulation was not established.

We have already shown that three immediate-early proteins, ICP4 ICP0, and ICP 7 play a role in regulating both viral and cellular genes. All three of the HSV-1 immediate-early proteins are nuclear phosphoproteins that are able to regulate the expression of other genes. ICP4 is the major transcriptional activator of HSV-1, although it represses its own expression $(6,17,26)$. It has been reported to bind DNA nonspecificically (21), but it also binds to some of its target sites in a sequence-specific pattern. Its high affinity binding sites have been identified as ATCGTCNNNNYGRC (where $\mathrm{R}$ is purine, $\mathrm{Y}$ is pyrimidine, $\mathrm{N}$ is any base $(20,44)$, and al of its binding sites conform to the consensus sequence RTCGTCNNYNYSG (where $R$ is purine, $Y$ is pyrimidine, $\mathrm{S}$ is $\mathrm{C}$ or $\mathrm{G}$, and $\mathrm{N}$ is any base) (11). Early studies showed that the activation function o:ICP4 is independent on the specific binding. Imbalzano suggested that ICP4 may activate the 
expression of HSV-1 early and late genes by a mechanism that does not require sequence-specific binding (36). Similar to this suggestion, other laboratories demonstrated that the mutations in either the ICP4 target sequence or in the ICP4 binding domain did not affect its transactivation function $(64,65)$.

Early studies and my data showed: (i) ICP4 binding concensus binding sites were not found in the region from +332 bp to +513 bp within the exon 1 (J. Paulson, personal communication), and the binding of ICP4 to its target sequence might not be required for its activation function. (ii) The data derived from transient expression (CAT assay) showed that the region from +332 bp to +513 bp in the first exon of $c$-myc was important for the regulation of $c$-myc gene expression by HSV-1 infection. (iii) The data from EMSA and competition EMSA demonstrated that some cellular proteins bound to the DNA sequences in the region from $+332 \mathrm{bp}$ to $+513 \mathrm{bp}$. (iiii) The early data from this laboratory (46) and the data in this paper showed that the ICP27 inhibition of $c$-myc expression seemed mainly to inhibit the ICP4 mediated transactivation. Early studies also revealed that ICP27 was involved in the secondary host shutoff process. Taken together these observations, it is reasonable to speculate that cellular factor(s) is/are involved in the ICP4 mediated activation of human $c$-myc gene expression at the level of transcription. This speculation may also be supported by the early studies that human $c$-myc expression depends on the presence of cellular proteins. However, the previous studies, described above $(40,71,72)$, might also give rise to the possibility that ICP4 might bind to a site which was of the low affinity or high degeneracy type and the human $c$-myc gene expression might be activated by this binding. Therefore the possibilits that ICP4 directly transactivates human $c$-myc gene expression still can not be excluded.

In contrast, among these three immediate-early proteins, ICPO is the only one that activates all three kinetic classes $(\alpha, \beta, \gamma)$ of HSV genes, without apparent DNA sequence specificity $(17,1 \varepsilon$, $49,51,54)$. It is able to further enhance the expression of any gene that exhibits a basal level $\mathrm{cf}$ 
transcription (71). There are many reports which showed that ICP0 exhibits a synergistic transactivation with ICP4 $(71,72)$, and our cotransfection assay results are concordant with these reports. This synergistic transactivation may require the physical interaction between ICPO and ICP4 (71). Recent study also revealed that ICP4 appeared to be required for the nuclear localization of ICPO (72)

ICP27 is another HSV-1 immediate-early protein involved in the regulation of $c$-myc gene expression. Although early showed that ICP27 alone was able to inhibit the expression of $c$-myc gene, early data (46) and my experiments demonstrated that ICP27 mainly inhibited ICP4 mediated c-myc activation. Previous study revealed that ICP27 is involved in the secondary stage shutoff of the host proteins synthesis (31). When cells were infected with HSV-1 mutants deffetive ICP27, the shutoff host protein synthesis was greatly reduced.(59). Other studies showed that ICP27 regulated cellular genes expressions post-transcriptionally $(31,62,67)$, and that requlation (both activation and repression) was not dependent on the target gene promoters, but on their processing signals (62). For the inhibitory activity of ICP27, the presence of introns in the target genes were required. (62). These observations suggest that the inhibitory function of ICP27 we have observed in the regulation of human $c$-myc gene might also occur at the post-transcriptional level. If this is true, it is reasonable to consider the possibility that the mechanism of ICP27 repression of $c$-myc: gene expression might be due to inhibition of action of certain cellular proteins. These proteins, activated by ICP4, possibly and/or ICPO might be required for activating human \&-myc gene bybinding to the region from +332 to +513 within exon 1 . These possibilities support the speculatior that cellular regulatory factor(s) is/are involved HSV-1 mediated regulation of human $c$-myc gene: expression. ICP27 can also inhibit the nuclear localization of ICP0 (72), and reduce the ICP4ICP0 synergy. This would therefore inhibit the ICP4-ICP0 synergistic activation.

In summary, my experiments demonstrate that the HSV-l immediate-early proteins, ICPC, 
ICP4, ICP27 are the regulators of the human $c$-myc gene. The results of cotransfection experiment showed that the relative CAT activity observed for wild type $c$-myc plasmid is $16 \%$ for noncotransfection, $78.3 \%$ for the cotransfection of ICP4 alone, $100 \%$ for the cotrazsfection of ICP4/ICP0, and 5\% for the cotransfection of ICP4/ICP0/ICP27. The relative CAT activity for the mutated $c$-myc plasmid $-101 /+332-\Delta$ exon $1-c$-myc-CAT is $1.7 \%$ for non-cotransfection, $2.5 \%$ for cotransfection of ICP4 alone, $16 \%$ for cotransfection of ICP4/ICP0, and $0.9 \%$ for cotransfection of ICP4/ICP0/ICP27 (the CAT activity observed in wild type $c$-myc plasmid cotransfected with ICP4/ICP0 is set as $100 \%$ ). Therefore ICP4 is the major transactivator whereas ICP27 inhibits the expression of the $c$-myc gene. This inhibition was observed either at basal level of $c$-myc expression (minor effect) (46) or in the ICP4 mediated $c$-myc activation (major effect). This implied that cellular proteins may be involved, because of its host shutoff function. The cotransfection results, together with the HSV-1 superinfection results, also suggest that one of the responding element in the $c$-myc exon 1 is located at the region from +332 bp to +513 bp downstream of the P2. In addition, the results from the EMSA and competition EMSA show that some cellular proteins bound to this region (Picture 1). This also implies that cellular proteins may be involved in this regulation.

Taken together with the observations from Dr. Millette's previous studies (46) and earlier studies on the HSV-1 immediate-early proteins $(31,36,46,59,62,65)$, my results suggest that cellular regulatory factor(s) may be involved in the ICP4 mediated human $c$-myc gene activation. Hypotheoretically, ICP4 may activates cellular protein(s) which in turn bind(s) to their targe1 sequences in the $c$-myc gene and activate(s) $c$-myc gene expression. The exact mechanism o: HSV-1 immediate-early proteins mediated regulation of c-myc gene is still unclear and it need: further investigation.

In my opinion, Further study will include DNA footprinting. This experiment will give infor 
mation of the exact cellular proteins binding sites. From the data derived from the DNA footprint, these binding sites could be used to compare with the binding sites of known proteins. Thus the possible kinds of proteins bound to the $c$-myc gene may be obtained.

\section{ACKNOWLEDGEMENT}

I thank Dr.Millette for supporting me in my academic affairs and with part of my living expenses, and for helping me in laboratory skills. I also thank Lisa Mills and John Poulson for giving me help in laboratory techniques and in improving my language ability. 


\begin{tabular}{|l|c|c|c|c|c|c|c|c|c|c|}
\hline Subclones & \multicolumn{3}{|c|}{$-101 /+513-c-M y c-C A T$} & \multicolumn{1}{|c|}{$101 /+212-\Delta$ exon I-c-Myc-CAT } & \multicolumn{3}{|c|}{$-101 /+332-\Delta$ exon 1-c-Myc-CAT } \\
\hline Enzyme & $\begin{array}{c}\text { Hind } \\
\text { III }\end{array}$ & $\begin{array}{l}\text { Hind III } \\
\text { Pvu I }\end{array}$ & $\begin{array}{l}\text { Sma I } \\
\text { Cla I }\end{array}$ & $\begin{array}{l}\text { Hind } \\
\text { III }\end{array}$ & $\begin{array}{l}\text { Hind III/ } \\
\text { Pvu I }\end{array}$ & $\begin{array}{c}\text { Sma I/ } \\
\text { Cla I }\end{array}$ & Hind III & Xho I & Pst I & $\begin{array}{l}\text { Xho I/ } \\
\text { Pst I }\end{array}$ \\
\hline $\begin{array}{l}\text { Number of } \\
\text { observed } \\
\text { bands }\end{array}$ & 1 & 2 & no cut & 1 & 2 & no cut & no cut & 1 & 1 & 2 \\
\hline $\begin{array}{l}\text { Number of } \\
\text { expected } \\
\text { bands }\end{array}$ & 1 & 2 & no cut & 1 & 2 & no cut & no cut & 1 & 1 & 2 \\
\hline
\end{tabular}

Table 1. Results of restriction analysis in mini-gels for the subclones $-101 /+513-c-M y c-C A T,-101 /+212-$ $\Delta$ exon 1-c-Myc-CAT, and $-101 /+212-\Delta$ exon 1-c-Myc-CAT. The results indicate that the number of observed bands are consistence with that of the expected bands. See Fig. 10, and Fig.12 for the gel.

\begin{tabular}{|c|c|c|c|c|c|c|c|c|c|}
\hline Subclone & \multicolumn{3}{|c|}{$-101 /+513-\mathrm{c}-\mathrm{Myc}-\mathrm{CAT}$} & \multicolumn{3}{|c|}{$-101 /+212-\Delta$ exon 1-c-Myc-CAT } & \multicolumn{3}{|c|}{$-101 /+332-\Delta$ exon $1-\mathrm{c}-\mathrm{M}+\mathrm{c}-\mathrm{CAT}$} \\
\hline Enzyme & Pst I & EcoR I & $\begin{array}{l}\text { EcoR I/ } \\
\text { Not I }\end{array}$ & Pst I & EcoR I & $\begin{array}{l}\text { EcoR V } \\
\text { Not I }\end{array}$ & Pst I & EcoR I & $\begin{array}{c}\text { EcoR I/ } \\
\text { Not I }\end{array}$ \\
\hline $\begin{array}{l}\text { Number of } \\
\text { observed } \\
\text { bands }\end{array}$ & 1 & 2 & 2 & 1 & 2 & 2 & 1 & 2 & 2 \\
\hline $\begin{array}{l}\text { Number of } \\
\text { expected } \\
\text { bands }\end{array}$ & 1 & 2 & $3\left(\sec ^{-*}\right)$ & 1 & 2 & $3\left(\sec ^{-*}\right)$ & 1 & 2 & $3\left(\sec ^{-*}\right)$ \\
\hline $\begin{array}{l}\text { size of } \\
\text { observed } \\
\text { bands }\end{array}$ & $6.3 \mathrm{kbp}$ & $\begin{array}{l}0.94 \mathrm{kbp} \\
\text { and a lar-. } \\
\text { size band". }\end{array}$ & $\begin{array}{l}0.80 \mathrm{kbp} \\
\text { and a large } \\
\text { size band. }\end{array}$ & $6.0 \mathrm{kbp}$ & $\begin{array}{l}0.61 \mathrm{kbp} \\
\text { and a lar- } \\
\text { ge size } \\
\text { band". }\end{array}$ & $\begin{array}{l}0.46 \mathrm{kbp} \\
\text { and a lar- } \\
\text { ge size } \\
\text { band. }\end{array}$ & $6.10 \mathrm{kbp}$ & $\begin{array}{l}0.71 \mathrm{kbp} \\
\text { and a lar- } \\
\text { ge size } \\
\text { band. }\end{array}$ & $\begin{array}{l}0.55 \mathrm{kbp} \\
\text { and a large } \\
\text { size band. }\end{array}$ \\
\hline $\begin{array}{l}\text { size of } \\
\text { expected } \\
\text { bands }\end{array}$ & $6.3 \mathrm{kbp}$ & $\begin{array}{l}0.93 \mathrm{kbp} \\
\text { and } \\
5.37 \mathrm{kbp}\end{array}$ & $\begin{array}{l}146 \mathrm{bp} \text {, } \\
0.79 \mathrm{kbp} \text {, } \\
\text { and } \\
5.37 \mathrm{kbp}\end{array}$ & $6.0 \mathrm{kbp}$ & $\begin{array}{l}0.63 \mathrm{kbp} \\
\text { and } \\
5.37 \mathrm{kbp}\end{array}$ & $\begin{array}{l}146 \mathrm{bp}, \\
0.484 \mathrm{kbp} \text {, } \\
\text { and } \\
5.37 \mathrm{kbp}\end{array}$ & $6.08 \mathrm{kbp}$ & $\begin{array}{l}0.71 \mathrm{kbp} \\
\text { and } \\
5.37 \mathrm{kbp}\end{array}$ & $\begin{array}{l}146 \mathrm{bp}, \\
0.564 \mathrm{kbp}, \\
\text { and } 5.37 \\
\mathrm{kbp} \text {. }\end{array}$ \\
\hline conclusion & \multicolumn{8}{|c|}{ all subcloned plasmids are correct } & \\
\hline
\end{tabular}

Table 2. Results of the restriction analysis of the subcloned $c$-myc plasmids $-101 /+513-c-M y c-C A T$, $101 /+212-\Delta$ exon 1-c-Myc-CAT, and -101/+332- $\Delta$ exon 1-c-Myc-CAT in two different concentrations of agarose gel $(0.9 \%$ and $1.2 \%)$. The results indicate that both the number and sizes of observed bands are same or very close to those of the expected bands. The most convincing evidence that they are correct plasmids is derived from the measurement and comparison of the diagnostic bands. The size differences in these bands represent the deletion parts in the exon 1. The gels are shown in Fig. 10 (0.9\% gel) and Fig.13 (1.2\% gel for the diagnostic digestion by EcoR I and EcoR I/Not I).

"The sizes of the larger fragments in Fig. 13 can not be measured because of the concentration of the: agarose gel (1.2\%). The larger marker DNA fragments can not be separated well at the higher concentration gel.

"The 146 bp fragment in Fig. 13 is too small to be detected. The reason to examine the EcoR I/Not I band is that this band is really important for the diagnostic purpose. 


\begin{tabular}{|c|c|c|c|}
\hline Plasmids & HSV-1 & $\begin{array}{l}\text { CAT Activity (pmol }{ }^{3} \mathrm{H}- \\
\text { OAc Chloramphenicol/ } \\
\text { mg Protein } / \mathrm{h}\end{array}$ & $\begin{array}{l}\text { percentage of induced } \\
\text { CAT activity of the wild } \\
\text { type } c \text {-myc plasmid (\%) }\end{array}$ \\
\hline$-101 /+513-c-$ myc-CAT & - & $\begin{array}{r}5.8 \times 10^{3} \\
39.0 \times 10^{3} \\
\end{array}$ & \begin{tabular}{r|r|}
14.9 & \\
100.0 & \\
\end{tabular} \\
\hline$-101 /+212-\Delta$ exon 1-c-myc-CAT & + & $\begin{array}{l}1.9 \times 10^{3} \\
7.5 \times 10^{3}\end{array}$ & $\begin{array}{r}4.9 \\
19.2 \\
\end{array}$ \\
\hline$-101 /+513-c-m y c-C A T$ & + & $\begin{array}{r}7.2 \times 10^{2} \\
31.0 \times 10^{3} \\
\end{array}$ & $\begin{array}{r}23.2 \\
100.0 \\
\end{array}$ \\
\hline$-101 /+332-\Delta$ exon $1-c-$ myc-CAT & + & $\begin{array}{l}3.2 \times 10^{2} \\
5.1 \times 10^{2}\end{array}$ & $\begin{array}{l}10.3 \\
16.1\end{array}$ \\
\hline
\end{tabular}

Table 3. Relative CAT activities for the the wild type and mutated $c$-myc plasmids $-101 /+\$ 13-c$-mycCAT, $-101 /+212 \Delta$ exon $1-c$-myc-CAT, and $-101 /+332-\Delta$ exon $1-c$-myc-CAT in two separate HSV-1 superinfections. The CAT activity represents pmol chloramphenicol acetylated $/ \mathrm{mg}$ protein $/ \mathrm{h}$. The CAT activity of wild type $-101 /+513-c$-myc-CAT superinfected by HSV-1 is set as $100 \%$.

\begin{tabular}{|l|c|c|r|}
\hline Transfected plasmid & $\begin{array}{l}\text { Cotransfected } \\
\text { plasmid }\end{array}$ & $\begin{array}{l}\text { pmol 3H OAC Chloram- } \\
\text { phenicol/mg Protein/h }\end{array}$ & $\begin{array}{l}\text { percentage of induced } \\
\text { CAT activity of the wild } \\
\text { type } c \text {-myc p psmid (\%) }\end{array}$ \\
\hline & ICP4 & $9.4 \times 10^{3}$ & 78.3 \\
\hline$-101 /+513-c-M y c-C A T$ & ICP4/ICP0 & $1.2 \times 10^{4}$ & 100.0 \\
\hline & ICP4//CP0/CP27 & $6.0 \times 10^{2}$ & 5.0 \\
\hline & ICP4 & $3.0 \times 10^{2}$ & 2.5 \\
\hline$-101 /+332-\triangle$ exon 1-c-Myc-CAT & ICP4/ICP0 & $2.0 \times 10^{3}$ & 16.0 \\
\hline & ICP4/ICP0/CP27 & $1.1 \times 10^{2}$ & 0.9 \\
\hline
\end{tabular}

Table 4. Relative CAT activities for the the wild type and mutated $c$-myc plasmids $-101 /+513-c-M y c-$ CAT and $-101 /+332-\Delta$ exon 1-c-myc- CAT in two separate cotransfection experiments. The CAT activity represents pmol chloramphenicol acetylated $/ \mathrm{mg}$ protein $/ \mathrm{h}$. The CAT activity of wild type $-101 /+513-c-$ myc-CAT cotransfected with 1 CP4/ICP0 is set as $100 \%$. 


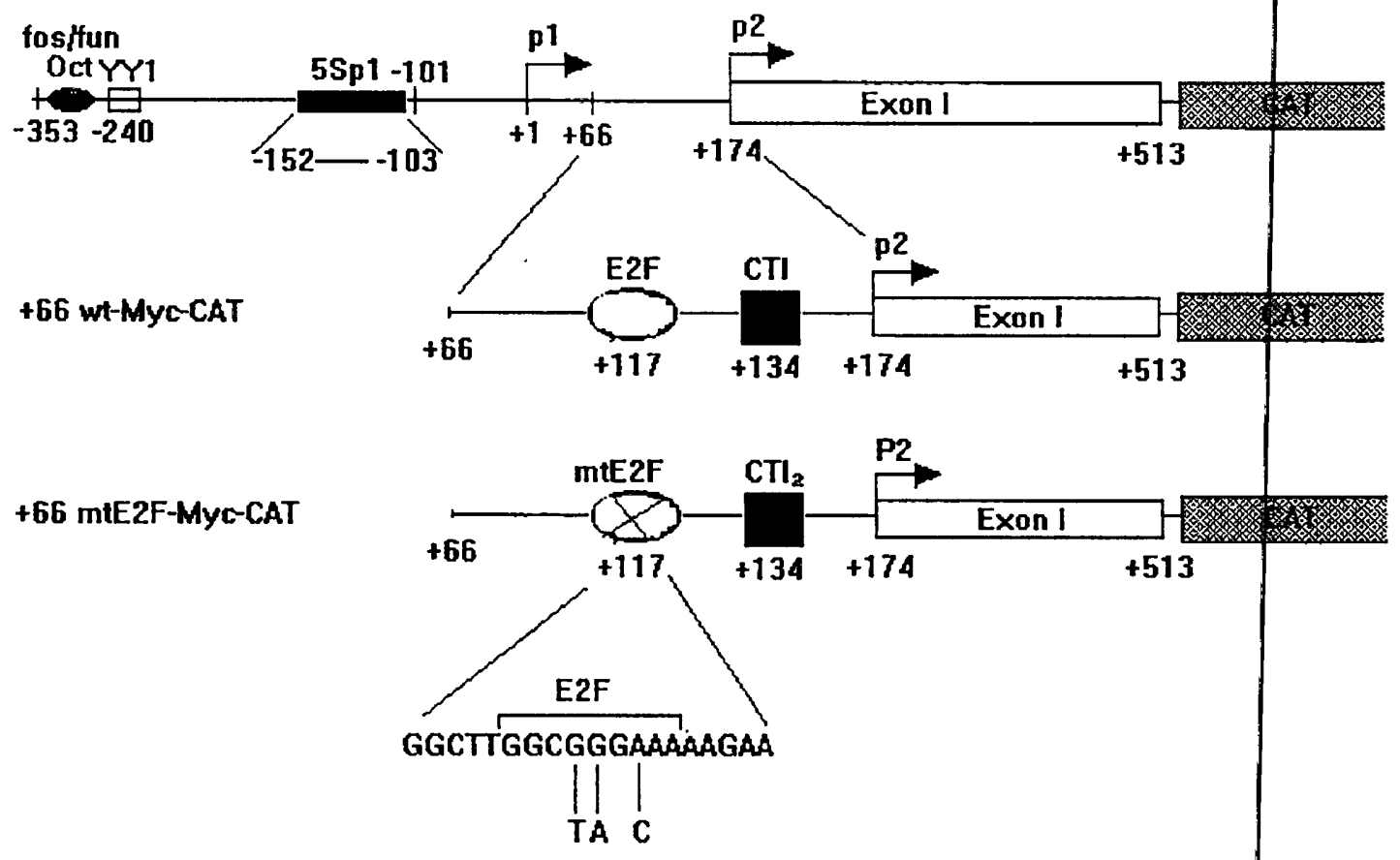

Fig.1. The maps of the wild type plasmid of +66-c-myc-CAT and the E2F-site mutatdd plasmid, $c$-myc+66 mtE2F-CAT. 


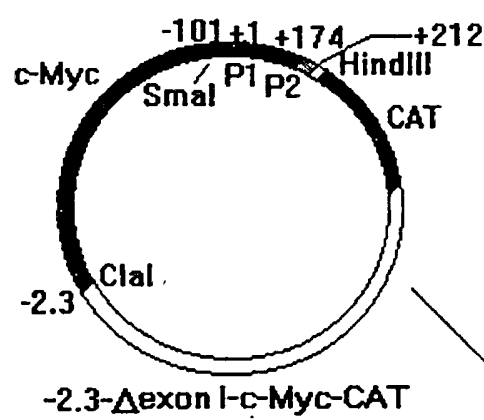

\author{
12
}
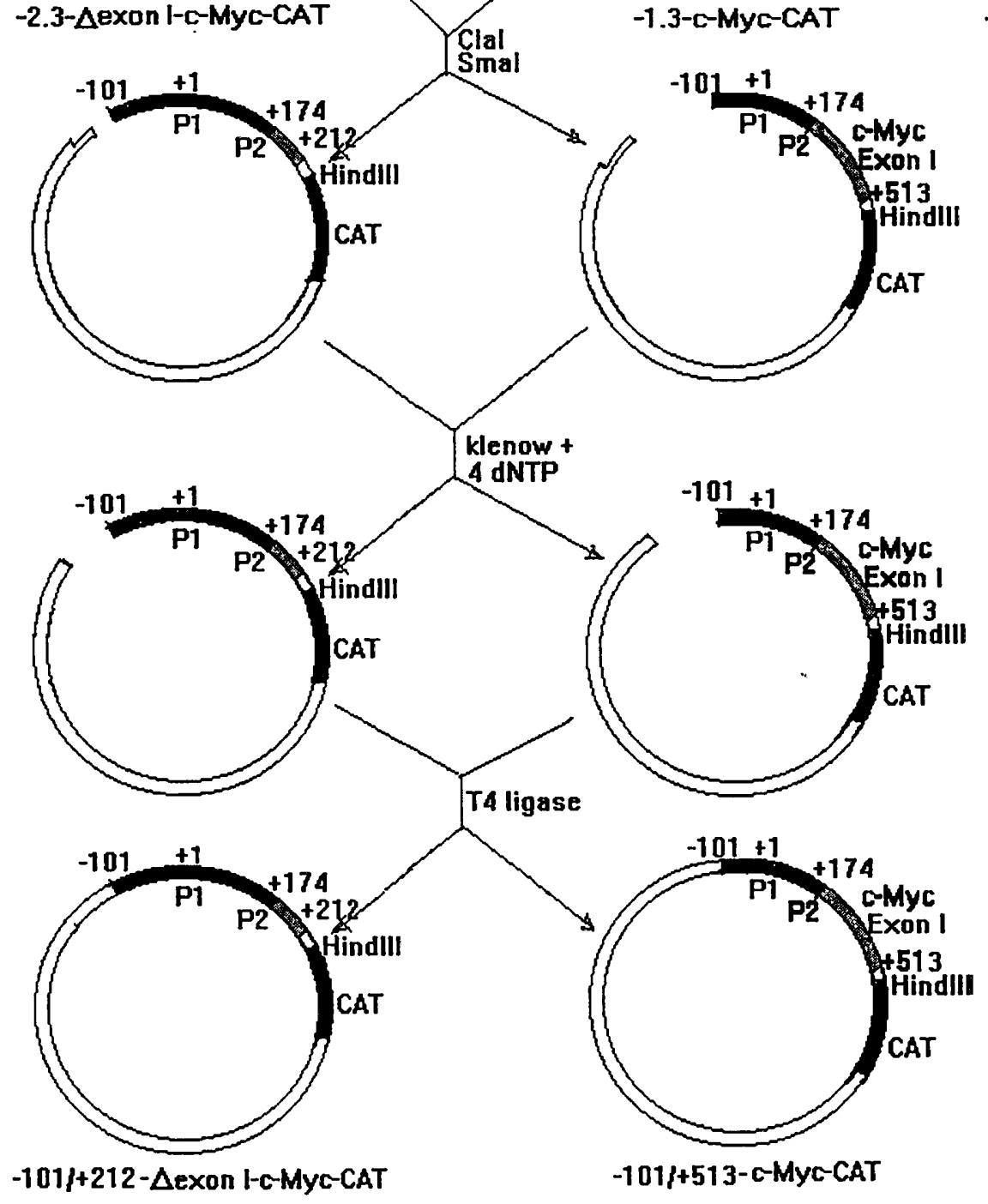

Fig.2 Map and steps in constructing wild type plasmids $-101 /+513-c$-myc-CAT and $-101 /+212-\Delta$ exon $1-c-m y c-C A T$. The vector plasmid is pBR322. 


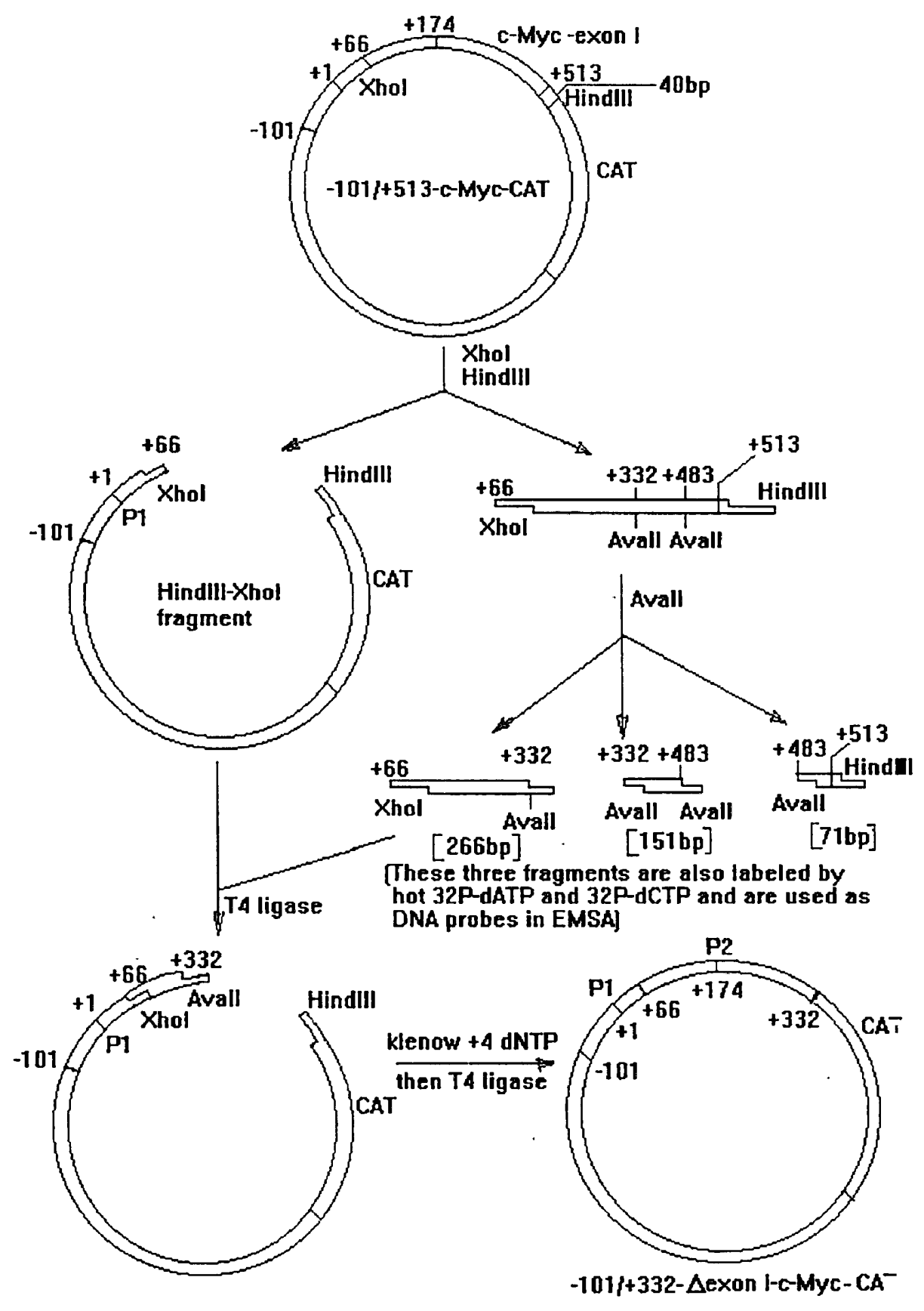

Fig.3 Map and steps in constructing the subcloned plasmid -101/+332plasmid is pBR322. The fragments used as probes in electrophoretic mobility shift assay (EMSA) and in competition EMSA are also shown. 

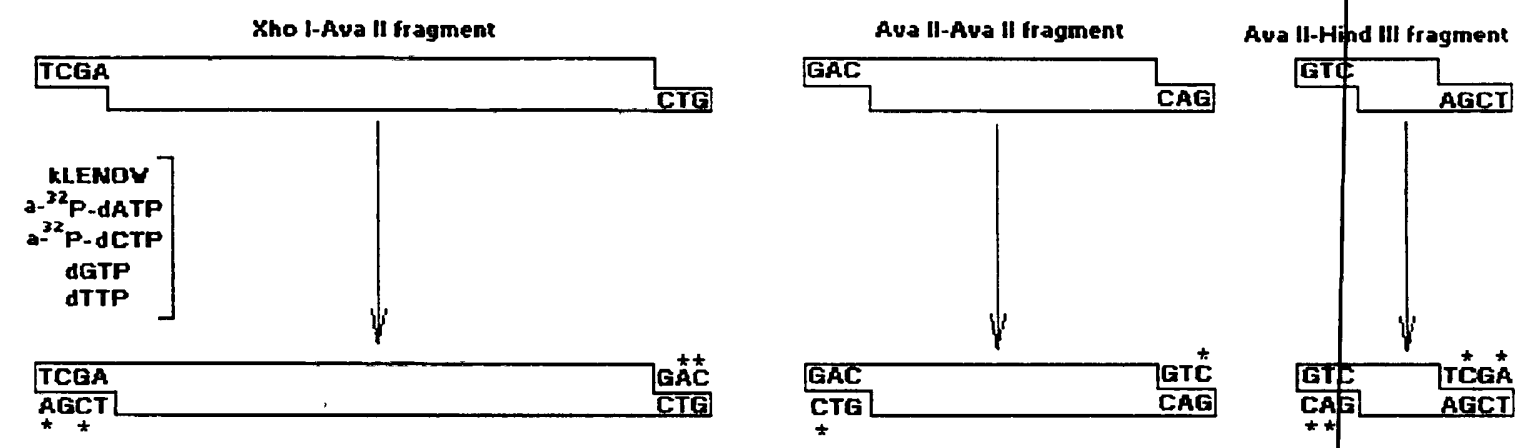

Fig.4. Diagram of the DNA probes prepared. * represents $\alpha-{ }^{32} \mathrm{P}$-labeled deoxynucleotides. All three probes were labeled by Klenow fill-in method.

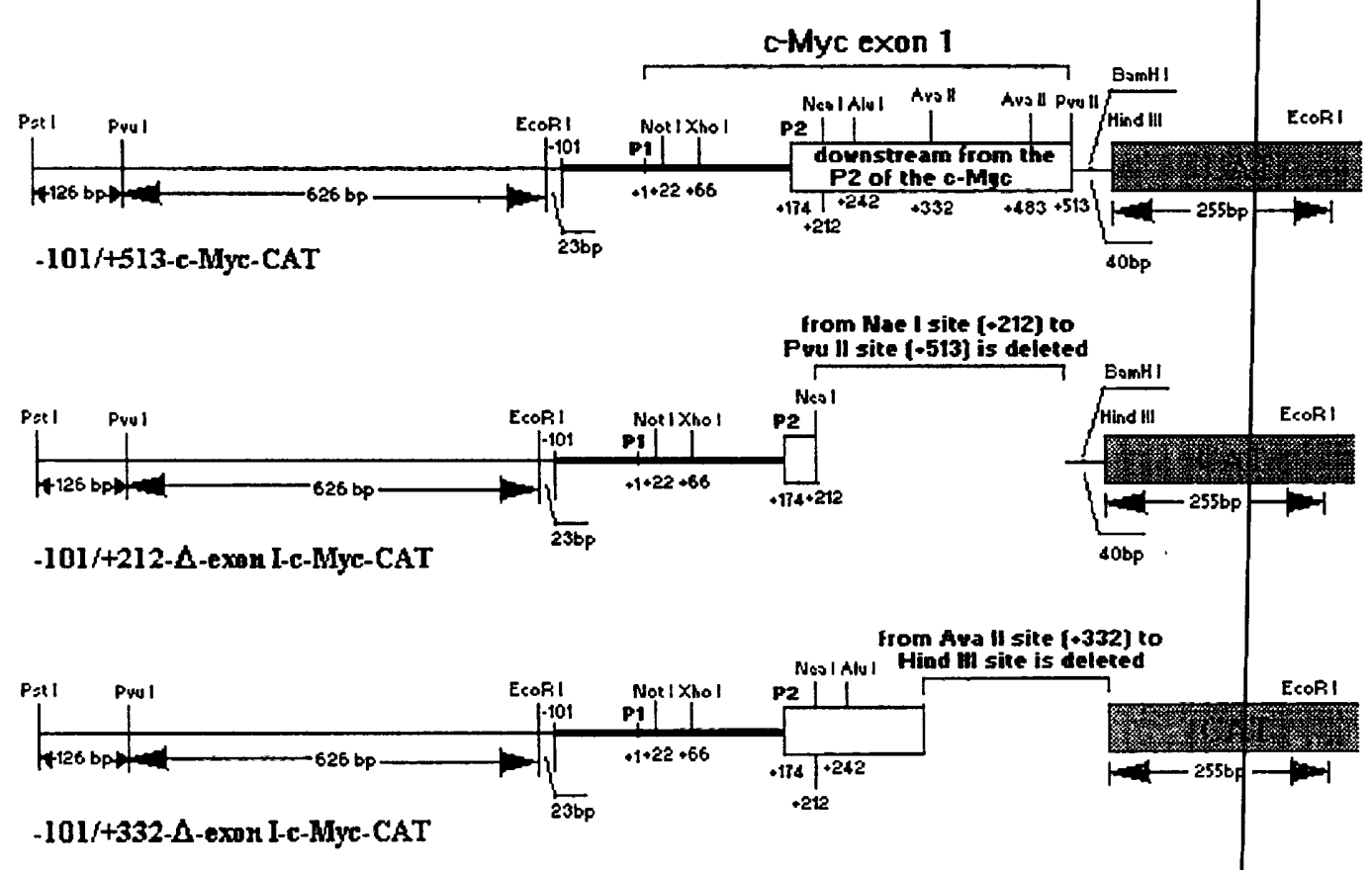

Fig.5. The restriction maps of the three subcloned $c$-myc plasmids, $-101 /+513-c$-myk-CAT, $-101 /+212-\Delta$ exon $1-c-$ myc-CAT, and $-101 /+332-\Delta$ exon $1-c-$ myc-CAT. The deleted parts of the two deletion mutated $c$-myc plasmids are also shown in this figure. 


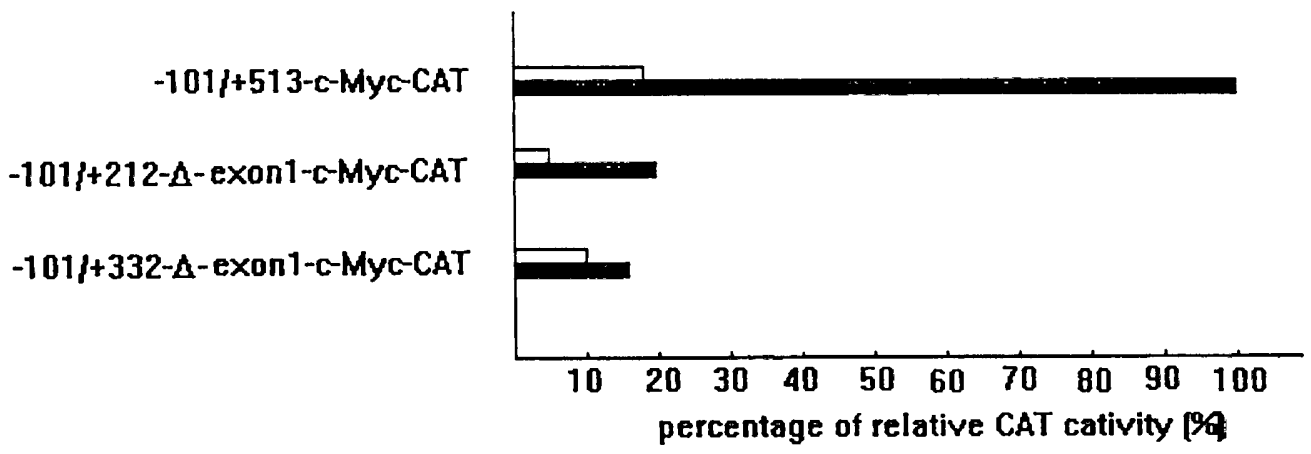

Fig.6. The relative CAT activities (use the CAT activity of the wild-type c-myc plasmid superinfected with HSV-1 as $100 \%$ ) of the three subclones, $-101 /+513-c$-myc-CAT, $-101 /-212$ $\Delta$ exon 1-c-myc-CAT, and -101/+332- $\Delta$ exon 1-c-myc-CAT in two separate HSV-1 infections. The CAT activity of $100 \%$ represents pmol chroramphenicol acetylated $/ \mathrm{mg}$ protein $/ \mathrm{h}$.

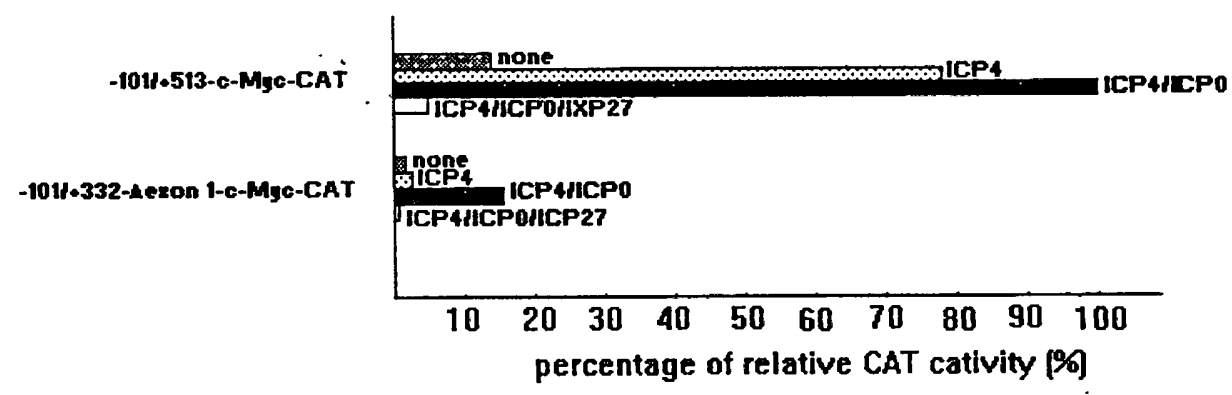

Fig.7. The relative CAT activities in two separate cotransfection assays (use wild type =-myc plasmid cotransfected with ICP0/ICP4 as $100 \%$ ) for subclones $-101 /+513-c$-myi-CAT and $-101 /+332-\Delta$ exon $1-c$-myc-CAT. The CAT activity of $100 \%$ represents pmol chroramphenicol acetylated/mg protein $/ \mathrm{h}$. 


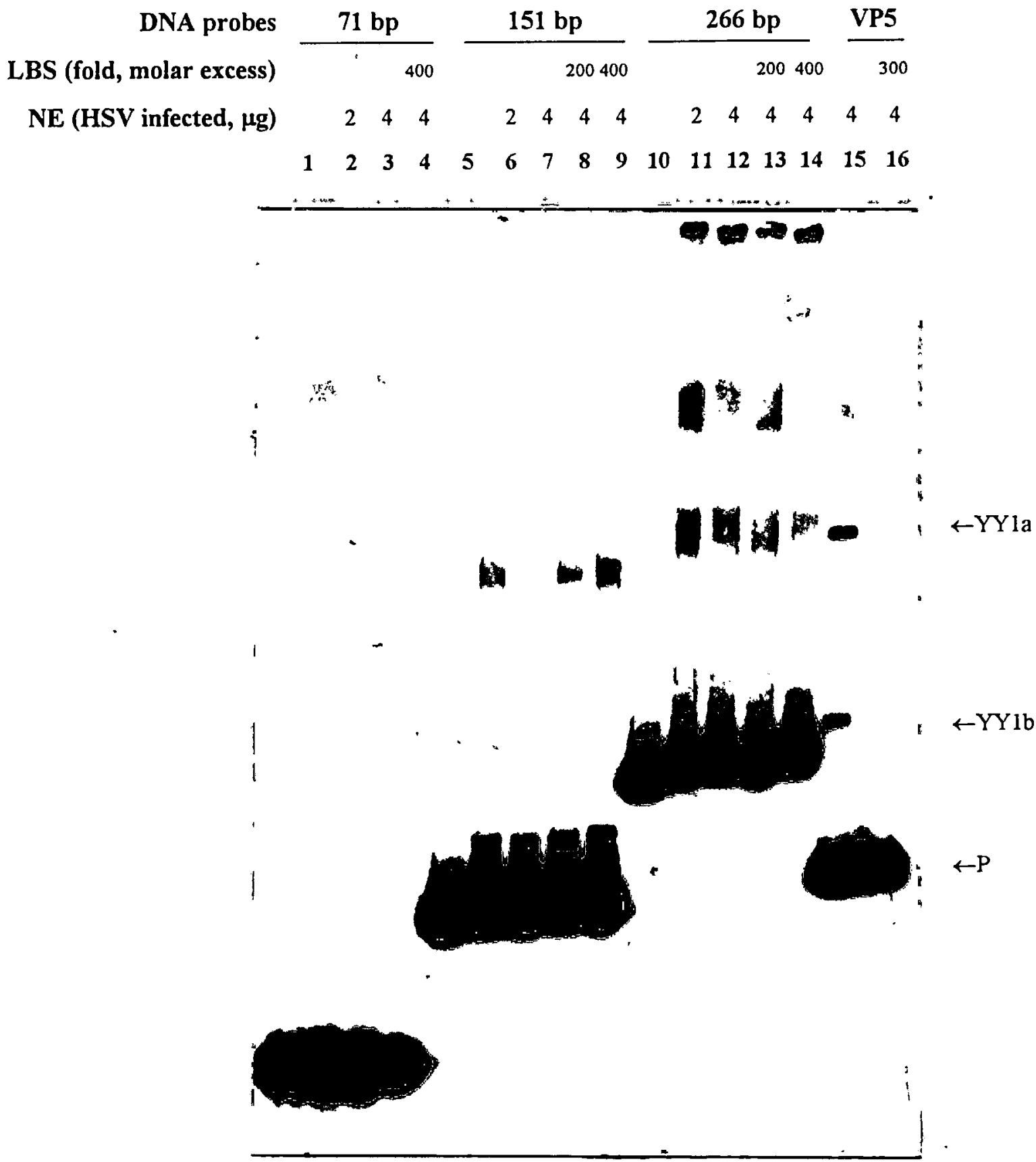

Fig.8. Results of the electrophoretic mobility shift assay (EMSA) and competition EMSA. The probes used in this experiment are $71 \mathrm{bp}$ Ava II-Hind III fragment, $151 \mathrm{bp}$ Ava II-Ava II fragment, and $266 \mathrm{bp}$ Xho I-Ava II fragment, and a 164 bp fragment from VP5 promoter is used as the positive control. A nonradiolabled oligonucleotide (LBS) containing YY1 binding site is used to compete with radiolabled probes. All probes are bound with proteins in the EMSA, but only 71 bp probe is competed with LBS (lane 4). P represents free probe. 
DNA probes

$\mathrm{C}_{2}$ (fold, molar excess)

LBS (fold, molar excess)

NE (HSV uninfected, $\mu g$ )
222 bp

VP5

400

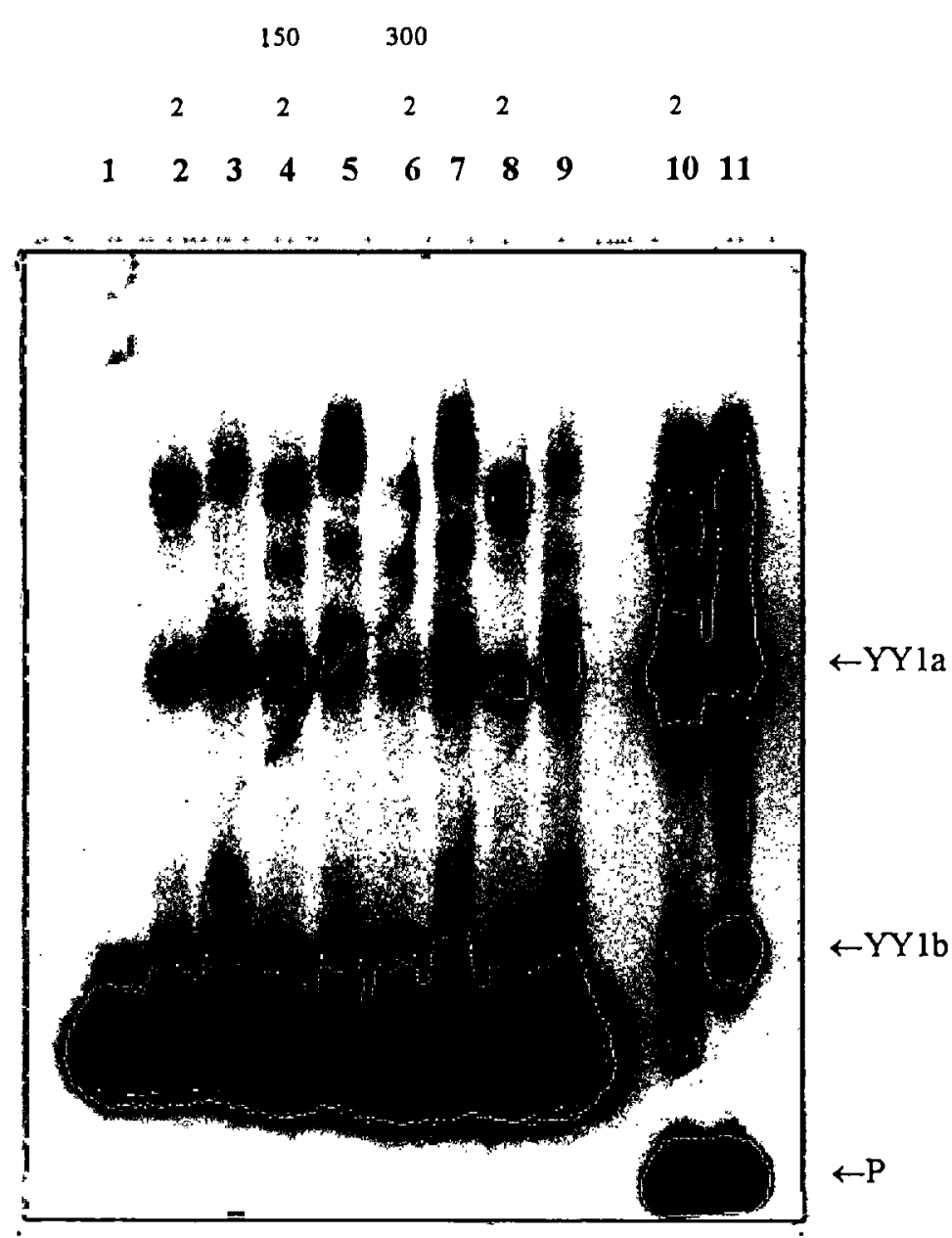

Fig.9. Result of the competition electrophoretic mobility shift assay using unlabeled oligonucleotide $\mathrm{C}_{2}$ as a negative control. The probe used in this experiment is a $222 \mathrm{bp} \mathrm{Ava} \mathrm{II-Hind} \mathrm{III} \mathrm{fragment,} \mathrm{spanning}$ from the Ava II site at +332 to the Hind III site (see Fig.5). The result shows that the binding of protein (YY1) to this probe is competed by unlabeled oligonucleotide LBS, but it is not competed by unlabeled oligonucleotide $\mathrm{C}_{2}$ (See lane $2,4,6,8$,). P represents the free probe. VP5 probe is used as a control. 
A.

$\begin{array}{lllllll}1 & 2 & 3 & \lambda & 4 & 5 & 6\end{array}$

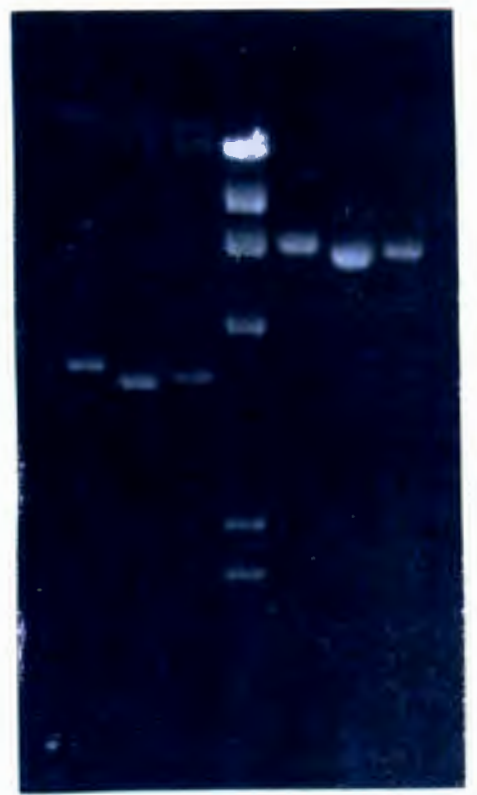

B.
$\begin{array}{lllllllllllllll}\lambda & 1 & 2 & 3 & 4 & 5 & 6 & 7 & 8 & 9 & 10 & 11 & 12 & 13\end{array}$

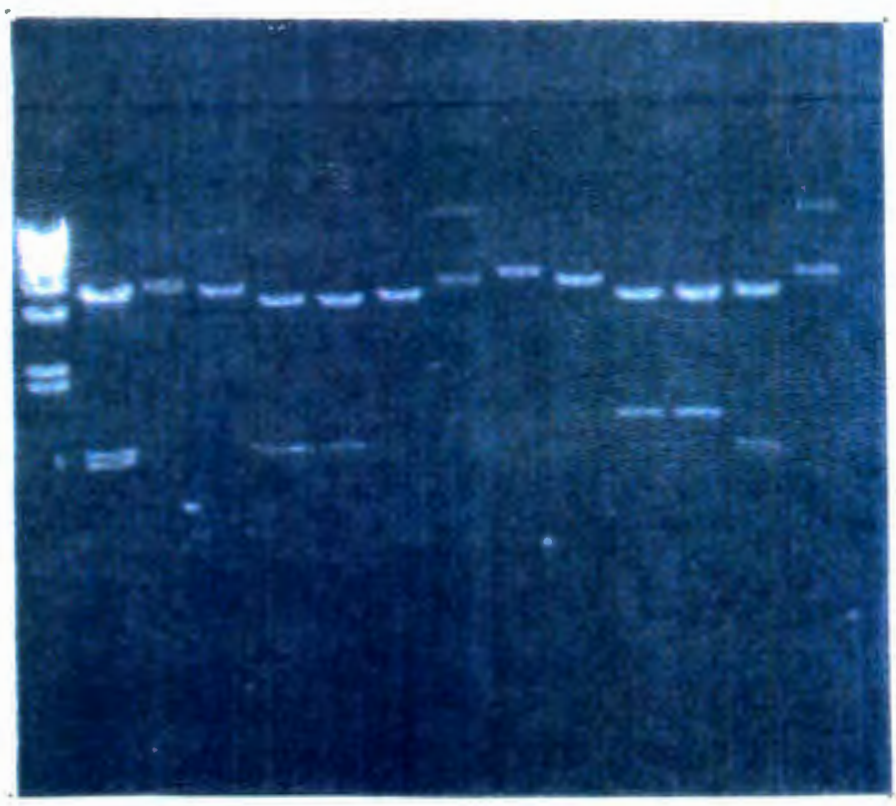

Fig.10. Two separate agarose gels for the restriction analysis of the wild type $c$-myc plasmid $-101 /+513$ $c$-myc-CAT and mutated $c$-myc plasmid $-101 /+212-\Delta$ exon 1-c-myc-CAT. (A) Pst I digestion to generate linear form of these two subclones (lane 4 for wild type $c$-myc plasmid -101/+513-c-myc-CAT and lane 5 for mutated $c$-myc plasmid -101/+212- $\Delta$ exon 1-c-myc-CAT). Lane 3 is the Pst I digestion of $-101 /+212-$ $\Delta$ exon 1-c-myc-CAT (the size is shown in Table 4). The gel concentration is $0.9 \%$ and the running buffer is $0.5 \mathrm{X}$ TBE. (B) The digestion of these two subclones by different endonuclease enzymes (lanes 2 to 7 for $-101 /+212-\Delta$ exon 1-c-myc-CAT and lanes 8 to 13 for $-101 /+513-c-$ myc-CAT. Lanes 3 and 9 show the linearization of these two plasmids by the Hind III digestion. Lanes 4, 5, 6, 10, 11, and 12 show the Pvu I/Hind III and EcoR I digestion to produce two bands. Lanes 7 and 13 show that the endonucleases Sma I and $\mathrm{Cla} I$ can not digest these two subclones. The gel concentration is $1 \%$ and the running buffer is $0.5 \mathrm{X}$ TBE. 


\section{$1 \quad 2 \quad 3 \quad 4556$}

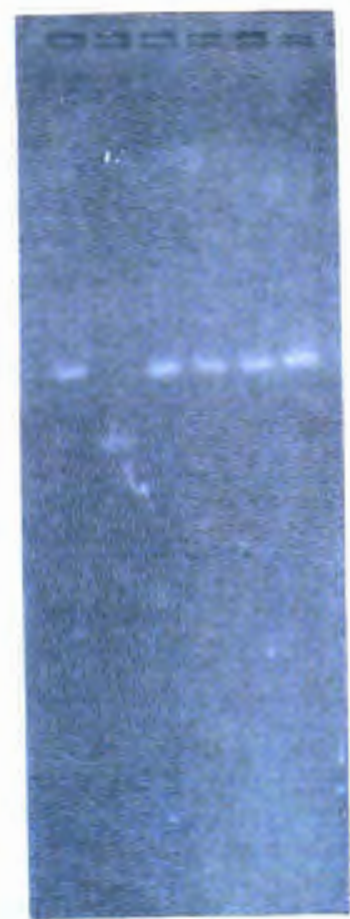

Fig.11. The Not I-Hind III fragment is analyzed by the endonucleases Xho I, Pvu II, Alu I,Ava II, and Hinf I. The gel concentration is $4 \%$ and the running buffer is $0.5 \mathrm{X}$ TBE. The undigested Not I-Hind III fragment (the size of this fragment was previously proven to be correct) is used as size marker. The picture shows that this fragment is only digested by Xho I to generate a 40 bp smaller fragment (lane 2). 


\section{$\begin{array}{lllllllllllllll}1 & 2 & 3 & 4 & 5 & \lambda & 6 & 7 & \lambda & 8 & 9 & 10 & 11 & 12 & 13\end{array}$}

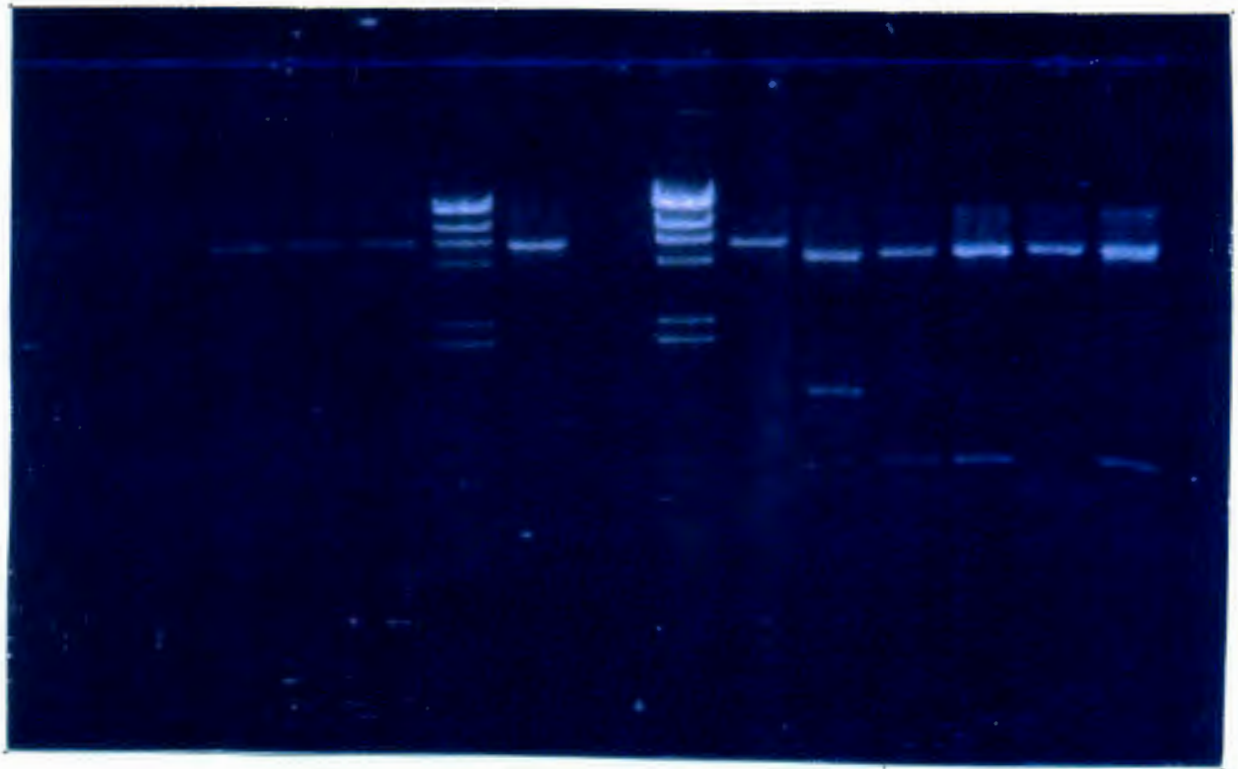

Fig.12. Photograph of the mini agarose gel for the restriction analysis of the subclone $-101 /+332-\Delta$ exon 1 -c-myc-CAT. The gel concentration is $1 \%$ and the running buffer is $0.5 \mathrm{X}$ TBE. Lane $I$ is the uncut control. Lane 2 shows that this subclone can not be digested by Hind III. Lanes 3, 4, 6, and 8 show the linearization of this subclone by Xho I (lane 3), Pst I (lane 4), Hind III/Xho I (lane 6) and Hind III/Pst I. Lane 5 shows that the Xho I/Pst I digestion generates two bands (size shown in Table 4). Lane 10 shows the two bands generated by Xho I/Pst I digestion. Lane 12 is the digestion by EcoR I (clearer photo is shown in Fig.3). Lanes 5, 9, 11, and 13 are the digestion of wild-type $c$-myc plasmid by Hind III (lane 5), Hind III/Pst I (lane 9), Xho I/Pst I (lane 11), and EcoR I (lane 13). 
$\begin{array}{llllllll}\lambda & 1 & 2 & 3 & \lambda & 4 & 5 & 6\end{array}$

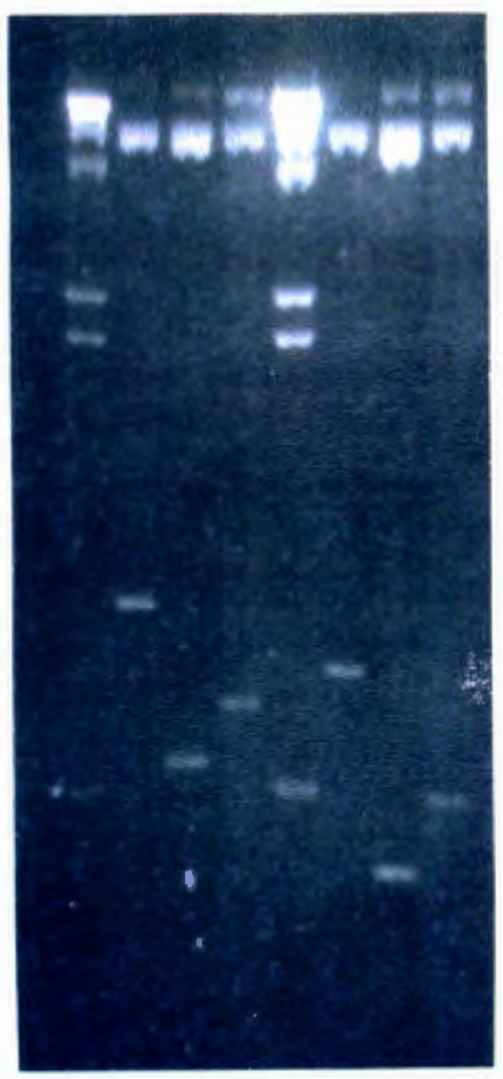

Fig.13. Photograph of the agarose gel for the diagnostic restriction analysis of the subcloned plasmids 101/+513-c-myc-CAT, 101/+212- exon 1-c-myc-CAT, 101/+332- $\Delta$ exon 1-c-myc-CAT. The gel concentration is $1.2 \%$ and the running buffer is $0.5 \mathrm{X}$ TBE. Lanes 1,2 , and 3 show the EcoR I digestion of these three plasmids. Lanes 4, 5, and 6 show the EcoR I/Not I digestion of these three plasmids. 


\section{RERERENCES}

1. Bentley, D. L., \& M.Groudine. 1986. A block to elongation is largely res วonsible for decreased transcription of $c$-myc in differentiated HL60 cells. Nature, 321:702-706.

2. Bernard, O., S. Cory, S. Gerondakis. E. Webb, and J. M. Adams. 1983. Sequence of the murine and human cellular myc oncogenes and two modes of myc transcription resulting from chromosome translocation in B lymphoid tumors. EMBO. J., 2:2375-2385.

3. Cai, W., T. L. Astor, L. M. Liptak, C. Cho, D. M. Coen, and P. A. Schaffer. 1993. The herpes simplex virus type 1 regulatory protein ICP0 enhances virus replication during ac/ute infection and reactivation from latency. J. Virol., 67:7501-7512.

4. Chen, S., L.Mills, P. Perry, S. Riddle, R. Wobig, R. Lown, and R. L. Millette. 1992. Transactivation of the major capsid protein gene of herpes simplex virus type 1 requires a cellular transcription factor. J. Virol., 66:4304-4314.

5. Dalla-Favera, R., M. Bregui, J. Erikson, D. Patterson, R. C. Gallo, and C. M. Croce. 1982. Human $c$-myc onc gene is located on the region of chromosome 8 that is translocated in Burkitt. lynmphoma cells. Proc. Natl. Acad. Sci. USA., 79: 7824-7827.

6. Deluca, N. A., A. M. McCarthy, and P. A. Schaffer. 1985. Isolation and characterization of deletion mutants of herpes simplex virus type 1 in the gene encoding immediate-early regulatoryprotein ICP4. J. Virol.. 56:558-570.

7. Deluca, N. A., and P. A. Schaffer. 1985. Activation of immediate-early, early, and late promoters by temperature-sensitive and wild-type forms of herpes simplex virus type 1 protein ICP4. MCB., 5:1997-2008.

8. Deluca. N. A., and P. A. Schaffer. 1988. Physical and functional domains of the herpes simplex virus transcriptionasl regulatory protein ICP4. J. Virol., 62:732-743. 
9. Desai, P., R. Ramesh, L. Zhi-Wu, O. Bella, G. Joseph, and L. Myron. 1993. The RRl gene of herpes simplex virus type $I$ is uniquely trans activated by ICP0 during infecticn. J. Virol.. 67:6125-6135.

10. DesJardins; E., and N. Hay. 1993. Repeated CT elements bound by zinc finger proteins control the absolute and relative activities of the two principal human $c$-myc promoters. MCB., 13:5710-5724.

11. DiDonato, J. A., J. R. Spitzner, and M. T. Muller. 1991. A predictive model for DNA recognition by the herpes simplex virus protein ICP4 . J. Mol. Biol., 219:451-470.

12. Dixon, R. A. F., and P. A. Schaffer. 1980. Fine-structure mapping and functional analysis of temperature-sensitive mutants in the gene encoding the herpes simplex virus type 1 immediate early protein VP 175. J. Virol., 36:189-203.

13. Dretzen, G., M. Bellard, P. Sassone-Corsi, and P. Chambon. 1981. A reliable method for the recovery of DNA fragments from agarose and acrylamide gels. Anal. Biochem., 1 12: 295-298.

14. Eick, D., and G. W. Bornkamm. 1986. Transcriptional arrest within the first exon is a fast control mechanism in c-myc gene expression. Nucl. Acids. Res., 14:8331-8346.

15. Erisman, M. D., P. G. Rothberg, R. E. Diehl, C. C. Morse, J. M. Spandorfer, and S. M Astrin. 1985. Deregulation of $c$-myc gene expression in human colon carcinoma is noaccompanied by amplification or rearrangement of the gene. MCB., 5:1969-1976.

16. Escot, C., C. Theillet, R. Liderean, F. Spyratos, M. Champeme, J. Gest, and R. Callahan. 1986. Genetic alteration of the $c$-myc proto-oncogene (MYC) in human primary breas carcinomas. Proc. Natl. Acad. Sci. USA., 83:4834- 4838.

17. Everett, R. D. 1984. trans-activation of transcription by herpes virus products: requiremert for two HSV-1 immediate-early polypeptides for maximum activity. EMBO. J., 3 3135-3141.

18. Everett, R. D. 1986. The products of herpes simplex virus type I (HSV-1) immediate-ear $y$ 
genes 1, 2 and 3 can activate HSV-1 gene expression in trans. J. Gen. Virol.. 67:2507-2513.

19. Everett, R. D. 1987. A detailed mutational analysis of Vmw 110. a trans-acting transactivator encoded by herpes simplex virus type 1. EMBO. J.. 6:2069-2076.

20. Faber, S. W. and K. W. Wilcox. 1986. Association of the herpes simplex viras regulatory protein ICP4 with specific nucleotide sequences in DNA. Nucl. Acid. Res., 14: 6067-6085.

21. Freeman, M. J., and K. L. Powell. 1988. DNA-binding porperties of a herpes simplex virus immediate early protein. J. Virol., 44:1084-1087.

22. Gelman, I. H., and S. Silvertein. 1985. Identification of immediate early genes from herpes simplex virus that transactivate the virus thymidine kinase gene. Proc. Natl. Acad. Sci. USA., 82:5265-5269.

23. Gignam, J. D., R. M. Lebovitz, and R. G. Roeder. 1983. Accurate transcription initiation by RNA polymerase II in a soluble extract from isolated mammalian nuclei. Nucl. Acids Res., 11:1475-1489.

24. Gorman, C. M., L. F. Moffat, and B. H. Howard. 1982. Recombinant genomes which express chloramphenicol acetyltransferase in mammalian cells. MCB.. 2:1044-1051.

25. Graham, F. L., and A. J. Van der Eb. 1973. A new technique for the assay of infectivity o1 human adenovirus 5 DNA. Virology, 52:456-467.

26. Gu, B., R. Rivera-Gonzalez, C. A. Smith, and N. A. DeLuca. 1993. Herpes simplex virus infected cell polypeptide 4 preferentially represses Spl-activated over basal transcription fron its own promoter. Proc. Natl. Acad. Sci. USA., 90:9528-9532.

27. Gu, B.. and N. Deluca. 1994. Requirements for activation of the Herpes Simplex Virus glycoprotein C promoter in vitro by the viral regulatory protein ICP4. J. Virol., 68:7953-7965.

28. Guzowski. J. F., J. Singh, and E. K. Wanger. 1994. Transcriptional activation of the herpes 
simplex virus type $1 \mathrm{U}_{\mathrm{L}} 38$ promoter conferred by the cis-acting downstream by a cellular transfection factor. J. Virol. 68:7774-7789.

29. Hann, S. R., M. W. King, D. L. Bentley, C. W. Anderson, and R. N. Eisenman. '988. A nonAUG transcriptional initiation in $c$-myc exon 1 generates and $\mathrm{N}$-terminally distinct protein whose synthesis is disrupted in Burkitt's lymphomas. Cell, 52:185-195.

30. Hardwicke, M. A., and R. M. Sandri-Goldin. 1994. The herpes simplex virns regulatory protein ICP27 contributes to the decrease in cellular mRNA levels during infection. J. Virol., 68:4797-4810.

31. Hardy, W. R., and R. M. Sandri-Goldin. 1994. Herpes simplex virus inhibits host cell splicing, and regulatory protein ICP27 is required for this effect. J. Virol., 68: 7790-7799.

32. Hay, N. Personal communication.

33. Hay, N., J. M. Bishop, and D. Levens. 1987. Regulatory elements that modulate expression of human $c$-myc. Genes. Dev., 1:650-671.

34. Hiebert. S. W., M. Lipp, and J. R. Nevins. 1989. E1A-dependent trans-act vation of the human MYC promoter is mediated by the E2F factor. Proc. Natl. Acad. Sci. USA.. 86:35943598.

35. Huang, C., S. A. Goodart, M. K. Rice, and J. F. Guzowski. 1993. Mutatioral analysis o1 sequences downstream of the TATA box of the herpes simplex virus type 1 major capsid proteir (VP5/UL 19$)$ promoter. J. Virol., 67:5109-5119.

36. Imbalzano, A. N., A. A. Shepard, and N. A. DeLuca. 1990. Functional relevance of specific interactions between herpes simplex virus type 1 ICP4 and sequence from the promoterregulatory domain of the viral thymidine kinase gene. J. Virol., 64:2620- 2631.

37. Janicke, R. U., F. H. Lee, and A. G. Porter. 1994. Nuclear c-Myc plays an important role in the cytotoxicity of tumor necrosis factor alpha tumor cells. MCB.. 14:5661-5670. 
38. Kelly, K., B. H. Cochran, C. D. Stiles, and P. Leder. 1983. Cell-specific regula1 on of the cmyc gene by lymphocyte mytogens and platelet-derived growth factor. Cell, $335: 60=610$.

39. Leib, D. A., D. M. Coen. C. L. Bogard, K. A. Hicks, D. R. Yager, D. M. Knipe. K. L. Tyler, and P. A. Schaffer. 1989. Immediate-early regulatory gene mutants define different stages in the establishment and reactivation of herpes simplex virus latency. J. Virol.. 63:759-768

40. Luscher, B., and R. N. Eisenman. 1990. New light on Myc and Myb. Part I. Myc. Genes.Dev., 4:2025-2035.

41. McGeoch, D. J., M. A. Dalrymple, A. J. Davison, A. Dolan,. M. C. Frame, D. McNab, L. J. Perry, J. E. Scott, and P. Taylor. 1988. The complete DNA sequence of the long un:que region in the genome of herpes simplex virus type 1. J. Gen. Viral., 69:1531-1574.

42. McLauchlan, J.. A. Phelan, C. Loney, R. M. Sandri-Goldin, and J. B. Clements. 1992. Herpes simplex virus IE63 acts as the post-transcriptional level to stimulate viral mRNA 3' processing. J. Virol., 66:6939-6945.

43. McCarthy, A. M., L. McMahan, and P. A. Schaffer. 1989. Herpes simplex virus type 1 ICP2T deletion mutants exhíbit altered patterns of transcription and are DNA deficient. J.|Virol., 63:1827.

44. Micheal, N., D. Spector, P. Mavromara-Nazos, T. M.Kristie, B. Roizman. 1988. The DNA binding properties of the major regulatory protein $\alpha 4$ of herpes simplex vircses. Science. 239:1531-1534.

45. Millette, R. Personal communication.

46. Millette, R. Data unpublished.

47. Mills, L. K.. Y. Shi.. and R. L. Millette. 1994. YY1 is the cellular factor shou previously bind to regulatory regions of several leaky-late $\left(\beta \gamma, \gamma_{1}\right)$ genes of herpes simplex virus type 1. I. Virol., 68:1234-1238. 
48. Mosca, J. D., P. M. Pitha, and G. S. Hayward. 1992. Herpes simplex virus infection selectively stimulates accumalation of beta interferon report gene mRNA by a posttranscriptional mechanism. J. Virol.. 66:3811-3822.

49. Nabel, G. J., S. A. Rice, D. M. Knipe, and D. Baltimore. 1988. Alternative machanisms for activation of human immunodeficiency virus enhancer in T cells. Science, 239:1299-1302.

50. Nordeen, S. K., P. P. Green, and D. M. Fowlkes. 1987. LABORATORY METHODS. A rapid, sensitive, and inexpensive assay for chloramphenicol acetyltransfe-rase. DNA. 6:173-178.

51. O'hare, P., and G. S. Hayward,. 1985. Evidence for a direct role for both the 175,000- and 110,000-molecular-weight immediate-early proteins of herpes simplex virus in the transactivation or delayed-early promoters. J. Virol., 53:751-760.

52. Packham, G., and J. L. Cleveland. 1994. Ornithine decarboxylase is a mediakr of c-Mycinduced apoptosis. MCB., 14:5741-5747.

53. Piechaczyk, M., J. Blanchard, and P. Jeanteur. 1987. c-MYC gene regulation still holds its secret. Trends Genet., 3:47-51.

54. Quinlan, M. P., and.D. M. Knipe. 1985. Stimulation of expression of a herpes simplex virus DNA binding protein by two viral functions. MCB., 5:957-963.

55. Rice, S.A., and D. M. Knipe. 1990. Genetic evidence for two distinct Iransactivation functions of the herpes simplex virus $\alpha$ protein ICP27. J. Virol., 64:1704-1715.

56. Riggs, K. J., K. T. Merrell, G. Wilson, and K. Calame. 1991. Common factor 1 is $\varepsilon$ transcriptional activator which binds in the $c$-myc promoter, the skeletal $\alpha$-actin promoter, anc the immunoglobulin heavy-chain enhancer. MCB., 11:1765-1769.

57. Riggs, K. J., S. Saleque, K. Wong, K. T. Merrell, J. Lee, Y. Shi, and K. Calane, 1993. YinYang 1 activates the $c$-myc promoter. MCB., 13:7487-7495.

58. Roussel, M., S. Saule, C. Lagrou, C. Rommens, H. Beng, T. Graf, and D. Stehelin. 197؟ . 
Three new types of viral oncogene of cellular origin specific for haematcpoietic cell transformation. Nature, 281:452-455.

59. Sacks, W. R., C. C. Greene, D. P. Aschman, and P. A. Schaffer. 1985. Herpes simplex virus type 1 ICP27 is an essential regulatory protein. J. Virol., 55: 796-805.

60. Sacks, W. R., and P. A. Schaffer. 1987. Deletion mutants in the gene encodir.g the herpes simplex virus type 1 immediate-early protein ICP0 exhibit impaired growth in cell culture. J. Virol., 61:829-839.

61. Sambrook, J., E. F. Frisher, and T. Maniatis. 1989. Molecular cloning: a laboratory manual, 2nd ed. Cold Spring Harbor Laboratory, Cold Spring Harbor, N.Y.

62. Sandri-Goldin, R. M., and G. E. Mendoza. 1992. A herpes virus regulatory protəin appears to act post-transcriptionally by affecting mRNA processing. Genes.Dev., 6:848-863.

63. Shapira, M., F. L. Homa, J. C. Glorioso, and M. Levine. 1987. Regulation of the herpes simplex virus type 1 late $(\gamma 2)$ glycoprotein $C$ gene: sequences between base pairs -34 to +29 control transient expression and reponsiveness to transactivation by the prozucts of the 4 immediate early $(\alpha) 4$ and 0 genes. Nucl. Acid. Res., 15:3097-3111.

64. Shepard, A. A., and N. A. DeLuca. 1991. A second-site revertant of a defective herpes simplex virus ICP4 protein with restored regulatory activities and impaired DNA-binding properties. J. Virol., 65:787-795.

65. Smiley, J. R., D. C.Johnson, L. I. Pizer, and R. D. Everett. 1992. The ICP4 binding site in the herpes simplex virus type 1 glycoprotein $\mathrm{D}(\mathrm{gD})$ promoter are not essential for efficient $\mathrm{g} \Gamma$ transcription during virus infection. J. Virol., 66:623-631.

66. Smith, A., P. Bates, R. Rivera-Gonzalez, B. Gu, and N. A. DeLuca. 1993. ICP4, the majcr transcriptional regulatory protein of herpes simplex virus type 1 , forms a tripartite complex with TATA-binding protein and TFIIB. J. Virol., 67:4676-4687. 
67. Smith, I. L., M. A. Hardwicke, and R. M. Sandri-Goldin. 1992. Evidence that the herpes simplex virus immediate early protein ICP27 acts posttranscriptionally during infection to regulate gene expression. Virology, 186:74-86.

68. Stevens, J. G., E. K. Wagner, G. B. Devi-Rao, M. L. Cook, and L. T. Feldman 1987. RNA complementary to a herpesvirus $\alpha$ gene mRNA is prominent in latently infected neurons. Science, 235:1056-1059.

69. Thalmeier,K., H.Synovik, R.Mertz, E.Winnacker, and M.Lipp. (1988) Nuclear factor E2F mediated basic transcription and trans-activation by $\mathrm{Ela}$ of the human $\mathrm{MYC}$ promoter. Genes.Dev., 3:527-536.

70. Watson, D. K., M. C. Psallidopoulos, K. P. Samuel, R. Dalla-Favera, and T. S. Papas. 1983. Nucleotide sequence analysis of human $c$-myc locus, chicken homologue, and myelocytomatosis virus MC29 transforming gene reveals a highly conserved gene product. Proc. Natl. Acad. Sci. USA., 80:3642-3645.

71. Yao, F., and P. A. Schaffer. 1994 Physical interaction between the herpes simflex virus type 1 immediate-early regulatory proteins ICP0 and ICP4. J. Virol., 68: 8158-8168.

72. Zhu, Z, W. Cai, and P. A. Schaffer. 1994. Cooperativity among herpes simplex virus type 1 immediate-early regulatory proteins:ICP4 and ICP27 affect the intracellular localization of ICP0 J. Virol., 6 8:3027-3040. 